\title{
The Relationship between DNA Methylation and Antidepressant Medications: A Systematic Review
}

\author{
Lauren M. Webb ${ }^{1}\left(\mathbb{D}\right.$, Kathryn E. Phillips ${ }^{1}$, Man Choi Ho ${ }^{2}$, Marin Veldic ${ }^{2, *}$ and \\ Caren J. Blacker ${ }^{2}$ D \\ 1 Mayo Clinic Alix School of Medicine, Rochester, MN 55905, USA; Webb.Lauren@mayo.edu (L.M.W.); \\ Phillips.Kathryn@mayo.edu (K.E.P.) \\ 2 Department of Psychiatry and Psychology, Mayo Clinic, Rochester, MN 55905, USA; \\ Ho.Ada@mayo.edu (M.C.H.); Blacker.Caren@mayo.edu (C.J.B.) \\ * Correspondence: Veldic.Marin@mayo.edu; Tel.: +1-(507)-255-7164
}

Received: 24 December 2019; Accepted: 26 January 2020; Published: 28 January 2020

\begin{abstract}
Major depressive disorder (MDD) is the leading cause of disability worldwide and is associated with high rates of suicide and medical comorbidities. Current antidepressant medications are suboptimal, as most MDD patients fail to achieve complete remission from symptoms. At present, clinicians are unable to predict which antidepressant is most effective for a particular patient, exposing patients to multiple medication trials and side effects. Since MDD's etiology includes interactions between genes and environment, the epigenome is of interest for predictive utility and treatment monitoring. Epigenetic mechanisms of antidepressant medications are incompletely understood. Differences in epigenetic profiles may impact treatment response. A systematic literature search yielded 24 studies reporting the interaction between antidepressants and eight genes (BDNF, MAOA, SLC6A2, SLC6A4, HTR1A, HTR1B, IL6, IL11) and whole genome methylation. Methylation of certain sites within BDNF, SLC6A4, HTR1A, HTR1B, IL11, and the whole genome was predictive of antidepressant response. Comparing DNA methylation in patients during depressive episodes, during treatment, in remission, and after antidepressant cessation would help clarify the influence of antidepressant medications on DNA methylation. Individuals' unique methylation profiles may be used clinically for personalization of antidepressant choice in the future.
\end{abstract}

Keywords: antidepressants; DNA; methylation; epigenetics

\section{Introduction}

The World Health Organization (WHO) estimates $4.4 \%$ of the world's population lives with depression [1]. Major depressive disorder (MDD) is a debilitating, heterogeneous disease that afflicts all sociodemographic backgrounds and cultures and is the leading cause of disability worldwide [2]. Depressive disorders are associated with higher rates of medical comorbidities [3,4] and increased risk of suicide. In 2015, suicide became one of the top twenty causes of death in the United States and was the second leading cause of death among 15-29-year-olds globally [1]. The economic burden of depression is high, costing the US $\$ 83.1$ billion in 2000 [5]. Between 2005 and 2015, the total number of people living with depression increased by $18.4 \%$, with a global population increase of approximately $12.8 \%$ during this period, only partly explaining this increase [1,6]. As the prevalence of MDD continues to rise, the WHO predicts that depression will be the leading cause of disease burden by 2030 [7].

Currently available treatments for MDD are often inadequate. Of patients treated for depression, $60-70 \%$ fail to achieve complete remission from symptoms [8]. For patients who display full or partial treatment response, most medications require weeks to months to take effect $[9,10]$ and that may be after multiple medication trials, each with undesirable side effects and financial burden. 
The etiology of MDD remains complex. Antidepressant medications still primarily target the monoamine system [11,12]. Genome-wide association studies of MDD in animals and humans have not fully explained the genesis of depression [13] or variable response to antidepressants [14]. For example, the discordance rate of MDD in monozygotic twins is heavily influenced by environmental factors [15]. Stressful life experiences, difficulties in role transition or functioning, and comorbid medical and psychiatric disorders have been associated with MDD across sociodemographic and cultural boundaries [16]. Since adverse life events do not always precipitate MDD, epigenetic mechanisms may impact the dynamic risk of depression [15].

Epigenetics describes modifiable, potentially heritable, non-nucleotide changes to DNA transcription [17-19]. These mechanisms can be both stable over time and dynamically responsive to environment. They can modify gene transcription/expression and organism physiology [20]. Epigenetics is crucial for normal neurogenesis and cell differentiation [9-11]. Experience-dependent DNA modulation provides one mechanism by which organisms and offspring can adapt to environmental changes [21]. Epigenetic responses occur following changes in nutrition, drugs, physical, and psychosocial factors [22].

Epigenetic mechanisms include post-translational histone modifications, noncoding RNAs, and DNA methylation [23]. Post-translational modifications to histone proteins (e.g., methylation, phosphorylation, acetylation) can increase or decrease DNA transcription [18,24]. Most RNA transcripts in humans do not encode functional proteins, such as microRNAs, piwiRNAs, endogenous small interfering RNAs, and long non-coding RNAs. On both the level of gene and chromosome, these noncoding RNAs are thought to regulate gene expression [25]. DNA methylation is the addition of a methyl to the cytosine pyrimidine ring of cytosine-phosphate-guanine dinucleotides ( $\mathrm{CpG})$ sites, which are especially numerous in the promoter regions [26-28]. DNA methylation typically suppresses gene expression by preventing transcription at the promoter [27-29] and by recruiting enzymes that promote suppression of gene expression to the chromatin. Thus, many genes display an inverse correlation between methylation level of the promoter and gene expression [20]. Although DNA methylation is known for its stability as a covalent modification [30], it is still responsive to environmental signals [28]. DNA methylation has been implicated in psychiatric disorders as a mechanism by which experience alters neuronal gene transcription [31], changing cognitive function and formation of long term memories [32] and emotional processing [33]. Altered DNA methylation and chromatin activation status has also been reported in human depression [26].

Because of the heterogeneity of MDD and typical onset of the disorder in adolescence or adulthood, the environment and DNA methylation likely play an important role in the pathogenesis and treatment of MDD [34,35]. Most antidepressant medications take weeks to months to exert therapeutic effects, despite higher monoamine levels in the brain occurring within days of initiating treatment. Antidepressant medications may interact with epigenetic mechanisms to create a "window of synaptic plasticity" [36]. One theory for the variability in response to antidepressants is the differential methylation of the CYP450 enzymes of the liver which metabolize antidepressant drugs, with altered enzyme expression possibly changing serum levels of the medications $[37,38]$.

In this systematic review, we review the literature studying the relationship between antidepressant use and DNA methylation of various genes in humans. Figure 1 illustrates how alterations in these genes' products, which have been studied in the context of their DNA methylation, may contribute to the pathogenesis of depressed mood state. Examining the DNA methylation profiles of individuals prior to treatment with antidepressant medications may allow for prediction of efficacy and identification of the best medication for a particular patient. Understanding the epigenetic effects of medications may also help elucidate the pathophysiology of MDD. 


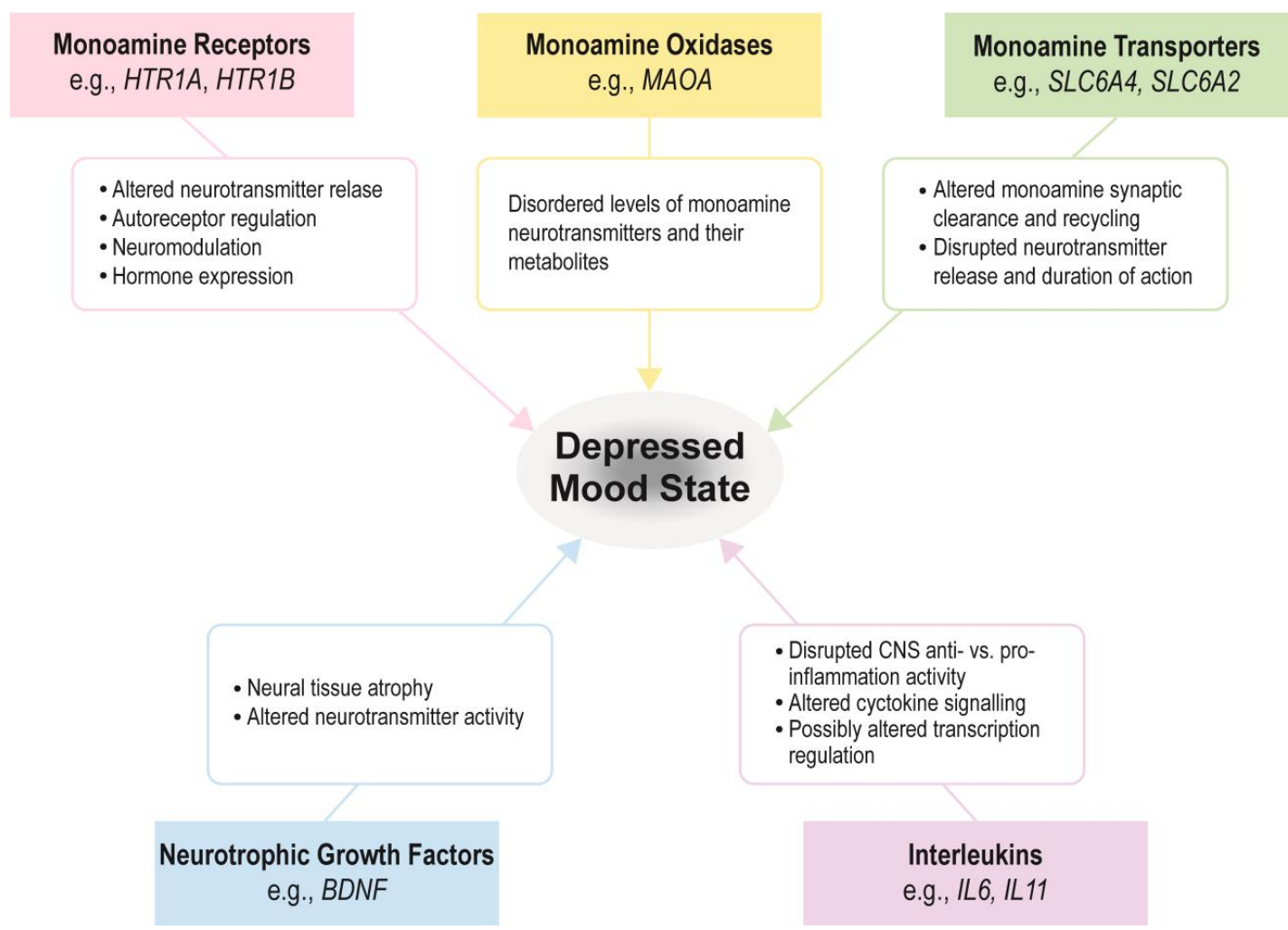

Figure 1. Plausible biologic mechanisms by which products of genes that have been studied in the context of antidepressants and DNA methylation contribute to depressed mood pathology.

\section{Results}

\subsection{BDNF (Brain-Derived Neurotrophic Factor)}

BDNF (brain-derived neurotrophic factor) promotes neuronal survival and synaptic plasticity [39] and is involved in learning, memory, and neurotransmitter release [40]. Animal studies show that $B D N F$ is differentially expressed across brain regions and is highly influenced by environmental stressors such as foot shock and maternal deprivation [41,42]. Blaze et al. 2017 demonstrated increased DNA methylation in BDNF exon IV in the prefrontal cortices of prenatally stressed rats compared to non-stressed controls [43]. The neurotrophic hypothesis of depression suggests BDNF decreases in depression and that antidepressants increase BDNF expression [44]. Human studies have demonstrated decreased brain levels of BDNF in untreated MDD, and increased brain BDNF in those treated with antidepressants $[45,46]$, possibly through alterations of DNA methylation. Table 1 summarizes the included studies of the relationship between BDNF DNA methylation and antidepressant medication use.

Peripheral blood mononuclear cells (PBMC) have been used as a proxy for central nervous system (CNS) tissue. PBMC are non-invasive to collect from living subjects and serve as surrogates for brain tissue molecular changes, though there can be limited coherence between PBMC and CNS biomarkers in various circumstances [47,48]. D'Addario et al. 2012 examined antidepressant effects on BDNF DNA methylation using PBMC from forty-nine human subjects diagnosed with bipolar disorder type 1 (BD1), forty-five subjects with bipolar disorder type 2 (BD2), and fifty-two healthy controls (HC) [49]. Antidepressants elevated BDNF promoter methylation compared to controls. Antidepressant classes used included selective serotonin or norepinephrine reuptake inhibitors (SSRIs, SNRIs) or tricyclic antidepressants (TCAs). BD2 patients taking antidepressants combined with mood stabilizers had significantly increased $B D N F$ promoter methylation and decreased $B D N F$ gene expression compared with healthy controls and BD1. The same team then compared BDNF promoter methylation in 
forty-one MDD patients and forty-four controls [50]. MDD patients taking antidepressants plus mood stabilizers had lower BDNF promoter methylation compared to those treated with antidepressants alone. Regardless of current mood state, patients treated with SSRI or SNRI had increased BDNF promoter methylation relative to MDD patients taking SSRI/SNRI plus mood stabilizer. A 2014 study found that the BDNF promoter of exon I was hypermethylated in a group of 210 MDD compared to $60 \mathrm{BD}(p=0.0089)$ and 327 unaffected controls $(p<0.000)$ [51]. In support of $\mathrm{D}^{\prime}$ Addario et al. 2012, the subset of 140 MDD patients treated with antidepressants had higher BDNF promoter methylation than the $25 \mathrm{MDD}$ patients not treated with antidepressants $(p=0.0019)$ and to controls $(p<0.0001)$ [51]. These studies suggest divergent action of mood stabilizing and antidepressant drugs on $B D N F$ promoter methylation.

Additional evidence that antidepressants increase BDNF promoter methylation in MDD came from an eight week trial of the SSRI, escitalopram, in eighty-five MDD patients [52]. Mean methylation across the entire $B D N F$ gene was not associated with antidepressant response $(p=0.052)$, however, remitters had significantly increased $B D N F$ promoter methylation at four specific amplicons of the $B D N F$ promoter: 1,3,4, and 5. Patients with low baseline methylation levels had impaired response to escitalopram treatment. Eight weeks of escitalopram was associated with significantly increased average $B D N F$ promoter and any amplicon methylation compared to pre-treatment in a subset of forty-four MDD subjects. In remitters, $B D N F$ promoter methylation was significantly increased after eight weeks of escitalopram treatment, while in the non-remitter group, there was no significant increase in methylation post-treatment [52].

Although studies using PBMC demonstrated that antidepressants can induce BDNF promoter methylation [50,51], a 2015 study of buccal cells from 251 elderly patients with depression and 773 HC reported that chronic depression was associated with increased BDNF promoter methylation in elderly patients, but there were no significant interactions with antidepressants (SSRIs, TCAs, or other classes) [53].

Some studies have investigated the relationship between BDNF methylation and treatment response. In a naturalistic study of 108 patients with MDD, Kang et al. 2013 measured PBMC BDNF promoter methylation and suicidal ideation (SI) severity over a twelve week treatment period with one of nine antidepressants (amitriptyline, bupropion, escitalopram, fluoxetine, imipramine, mirtazapine, paroxetine, sertraline, and venlafaxine) chosen clinically [54]. Twenty-one subjects had a history of previous suicide attempt. There was no significant difference between the type of antidepressant and SI severity. When the patients were divided into high and low pre-treatment $B D N F$ promoter methylation groups, lower methylation predicted significant improvement in SI severity. Higher BDNF promoter methylation was associated with male sex $(p=0.046)$, a history of suicide attempt $(p=0.035)$, and any suicidal ideation during antidepressant treatment $(p=0.013)$. Lower $B D N F$ promoter methylation was associated with reduced SI following antidepressant treatment [54].

In contrast, another group found that hypomethylation of $B D N F$ exon IV predicted poor response to antidepressant treatment [55]. They analyzed twelve CpG sites within BDNF exon IV in thirty-nine MDD patients. Pre-treatment methylation status at $\mathrm{CpG}$ position -87 predicted response to antidepressants. Patients without methylation at CpG-87 had a significantly higher risk for non-response than patients with methylation regardless of antidepressant class (SSRI, SNRI, mirtazapine, TCA, or monoamine oxidase inhibitor (MAO-I)). Patients with no methylation at CPG-87 showed a decrease in plasma BDNF levels during the first week of antidepressant treatment, which has previously been predictive of nonresponse to antidepressants [56]. DNA methylation at the twelve CpG sites did not significantly change from baseline to the end of treatment [55]. 
Table 1. Summaries of studies exploring relationship of antidepressants and BDNF DNA methylation.

\begin{tabular}{|c|c|c|c|c|}
\hline Reference & Genomic Region Studied & Study Description & Tissue Examined & Findings \\
\hline $\begin{array}{l}\text { D'Addario et al., } \\
2012 \text { [49] }\end{array}$ & $\begin{array}{l}\text { Exon I promoter (chr 11: } \\
27743 \text { 605-27 } 744379 \text { ) }\end{array}$ & $\begin{array}{l}\text { Milanese study of } B D N F \text { methylation using } \\
\text { fluorescence-based RT-PCR }{ }^{1} \text { in bipolar disorder (BD) } \\
\text { patients on mood stabilizers, BD patients on } \\
\text { antidepressants + mood stabilizers, and healthy controls. }\end{array}$ & $\begin{array}{l}\text { Peripheral blood } \\
\text { mononuclear cells } \\
\text { (PBMC) }\end{array}$ & $\begin{array}{l}\text { - BDNF promoter methylation was increased in BD2 compared to } \\
\text { controls, but not in BD1 compared to controls. } \\
\text { - BDNF promoter methylation was increased in patients using } \\
\text { antidepressants compared to controls and patients taking mood } \\
\text { stabilizers alone. }\end{array}$ \\
\hline $\begin{array}{l}\text { D'Addario et al., } \\
2013 \text { [50] }\end{array}$ & Exon I promoter & $\begin{array}{l}\text { Milanese study of } B D N F \text { methylation using } \\
\text { fluorescence-based RT-PCR in major depressive disorder } \\
\text { (MDD) on antidepressants, MDD on antidepressants + } \\
\text { mood stabilizer, and healthy controls. }\end{array}$ & PBMC & $\begin{array}{l}\text { - MDD patients treated with antidepressants (serotonin or } \\
\text { norepinephrine reuptake inhibitors (SSRIs or SNRIs)) alone had higher } \\
\text { BDNF promoter methylation compared with patients receiving } \\
\text { antidepressant + mood stabilizer. }\end{array}$ \\
\hline $\begin{array}{l}\text { Carlberg et al., } \\
2014 \text { [51] }\end{array}$ & Exon I promoter & $\begin{array}{l}\text { Austrian study of BDNF methylation using PCR on } \\
\text { bisulfite-converted genomic DNA from white, European } \\
\text { MDD, BD, and unaffected controls. } \\
\text { Subgroup of MDD patients analyzed for effects of } \\
\text { antidepressants on DNA methylation. }\end{array}$ & PBMC & $\begin{array}{l}\text { - MDD subgroup treated with antidepressants had significantly } \\
\text { increased } B D N F \text { promoter methylation compared to controls and MDD } \\
\text { patients not treated with antidepressants. } \\
\bullet \text { No increase in \% of methylated reference values in MDD without } \\
\text { antidepressant therapy compared to control subjects. }\end{array}$ \\
\hline $\begin{array}{l}\text { Wang et al., } \\
2018 \text { [52] }\end{array}$ & $\begin{array}{l}\text { Five CpG islands within } \\
\text { the promoter. }\end{array}$ & $\begin{array}{l}\text { Measured methylation of } B D N F \text { via PCR amplification of } \\
\text { bisulfate-converted DNA in Han Chinese MDD patients } \\
\text { before and after } 8 \text { weeks of } 10-20 \mathrm{mg} \text { escitalopram daily. }\end{array}$ & $\begin{array}{l}\text { Whole blood genomic } \\
\text { DNA isolate }\end{array}$ & $\begin{array}{l}\text { - Methylation of } 4 \text { amplicons in } B D N F(1,3,4 \text {, and 5) was significantly } \\
\text { associated with response to escitalopram after } 8 \text { weeks, with higher } \\
\text { methylation status associated with better response to escitalopram } \\
\text { • Patients with lower } L^{2} S^{2} \text { and higher DNA methylation responded } \\
\text { better to escitalopram than those with higher LES and lower methylation. } \\
\text { - After } 8 \text { weeks of escitalopram, average } B D N F \text { and any } B D N F \text { amplicon } \\
\text { methylation were significantly increased compared to baseline. } \\
\text { • In the remitter group, escitalopram treatment significantly increased } \\
\text { DNA methylation, while in the non-remitter group there was no } \\
\text { significant increase in } B D N F \text { methylation. }\end{array}$ \\
\hline $\begin{array}{l}\text { Januar et al., } \\
2015[53]\end{array}$ & Exon I and IV promoters & $\begin{array}{l}\text { Bisulfite conversion and PCR measurement of } B D N F \\
\text { methylation in }>65 \text {-year-old French patients with or } \\
\text { without depression. }\end{array}$ & Buccal swabs & $\begin{array}{l}\text { - After adjustment for age, sex, and antidepressant use, methylation of } \\
\text { CpG unit 3.4.5. of exon I and CpG-3 of promoter IV remained } \\
\text { significantly higher in depression. }\end{array}$ \\
\hline $\begin{array}{l}\text { Kang et al., } \\
2013 \text { [54] }\end{array}$ & $\begin{array}{l}\text { CpG-rich region of the } \\
\text { promoter between -694 } \\
\text { and -577 relative to } \\
\text { transcriptional start site, } \\
\text { including } 7 \text { CpG sites. }\end{array}$ & $\begin{array}{l}\text { Measured and averaged methylation at } 7 \mathrm{CpG} \text { sites of } \\
\text { BDNF promoter before } 12 \text { week antidepressant treatment } \\
\text { (SSRIs, bupropion, mirtazapine, venlafaxine, } \\
\text { amitriptyline, or imipramine) in Korean MDD patients. } \\
\text { Assessed suicidal ideation during the treatment period. }\end{array}$ & PBMC & $\begin{array}{l}\text { Patients with lower } B D N F \text { promoter methylation showed greater } \\
\text { improvement in } B^{3} S^{3} \text { over the treatment period than patients with } \\
\text { higher } B D N F \text { promoter methylation before antidepressant treatment. }\end{array}$ \\
\hline $\begin{array}{l}\text { Tadić et al., } \\
2014 \text { [55] }\end{array}$ & $\begin{array}{l}\text { Twelve CpG sites within } \\
\text { exon IV promoter }\end{array}$ & $\begin{array}{l}\text { Measured } B D N F \text { methylation status in MDD patients } \\
\text { before treatment with antidepressants and assessed } \\
\text { outcomes at the study endpoint (ranging from 2-6 weeks) } \\
\text { with HAM-D-2 } 21^{4} \text {. }\end{array}$ & PBMC & $\begin{array}{l}\text { - Baseline methylation at CpG-87 predicted antidepressant response: } \\
\text { Non-responders had a significantly lower methylated C-fraction than } \\
\text { responders. } \\
\text { • Patients without any methylation at CpG-87 had higher risk of } \\
\text { non-response to antidepressant than those with methylation. } \\
\text { • No significant effect of antidepressant class on the association between } \\
\text { CpG-87 methylation and antidepressant response. } \\
\text { •DNA methylation of the } 12 \text { investigated CpG sites in exon IV did not } \\
\text { change significantly during treatment from baseline to end point. }\end{array}$ \\
\hline
\end{tabular}


Table 1. Cont.

\begin{tabular}{|c|c|c|c|c|}
\hline Reference & Genomic Region Studied & Study Description & Tissue Examined & Findings \\
\hline $\begin{array}{l}\text { Kim et al., } \\
2015 \text { [57] }\end{array}$ & $\begin{array}{l}\text { Nine CpG sites within } \\
\text { exon VI promoter }\end{array}$ & $\begin{array}{l}\text { Measured methylation of promoter of } B D N F \text { in peripheral } \\
\text { blood of Korean ACS patients with and without any } \\
\text { depressive disorder. They randomized } 127 \text { depressed } \\
\text { participants to } 24 \text { weeks of escitalopram + ACS treatment } \\
\text { and } 128 \text { to placebo + ACS treatment. The remaining } 123 \\
\text { patients received standard medical treatment for ACS. }\end{array}$ & $\begin{array}{l}\text { Peripheral blood } \\
\text { leukocytes }\end{array}$ & $\begin{array}{l}\text { - In the escitalopram-treated group, significantly higher average } \\
\text { methylation \% was found in participants with remission compared to } \\
\text { those who did not remit. } \\
\text { - Persistence of baseline depressive disorder } 1 \text { year later was associated } \\
\text { with a higher methylation at CpG-1 and higher average methylation \% } \\
\text { only in the placebo and the medical treatment-only groups, and not in } \\
\text { the escitalopram group. }\end{array}$ \\
\hline $\begin{array}{l}\text { Chen et al., } \\
2011[58]\end{array}$ & Exon IV promoter & $\begin{array}{l}\text { Assessed relationship between } B D N F \text { methylation, MDD, } \\
\text { antidepressant use, exon IV expression, and H3K27 } \\
\text { tri-methylation in Caucasian male French Canadians } \\
\text { post-mortem. }\end{array}$ & $\begin{array}{l}\text { Prefrontal cortex } \\
\text { (post-mortem) }\end{array}$ & $\begin{array}{l}\text { - Antidepressant use was associated with significantly lower H3K27 } \\
\text { methylation levels in } B D N F \text { exon IV promoter than the MDD without } \\
\text { antidepressant and control groups. }\end{array}$ \\
\hline $\begin{array}{l}\text { Lopez et al., } \\
2013 \text { [59] }\end{array}$ & Exon IV promoter & $\begin{array}{l}\text { Measured BDNF H3K27 trimethylation levels with ChIP } \\
\text { and peripheral } B D N F \text { mRNA }^{6} \text { at baseline and after } 8 \\
\text { weeks of citalopram. Subjects were divided into } \\
\text { responders and non-responders based on final } \\
\text { HAM-D score. }\end{array}$ & Peripheral blood & $\begin{array}{l}\text { - Trimethylation of H3K } 27 \text { at } B D N F \text { exon IV was significantly decreased } \\
\text { after } 8 \text { weeks of citalopram in responders to citalopram, but not in } \\
\text { non-responders. } \\
\text { - Significant negative correlation between change in depression severity } \\
\text { and change in trimethylated H3K27 expression. }\end{array}$ \\
\hline
\end{tabular}


In $2015 \mathrm{Kim}$ et al. investigated BDNF gene methylation in acute coronary syndrome (ACS) patients with and without depression [57]. Of the 969 ACS patients, 378 had a depressive disorder. The depressed patients were randomized to receive a twenty-four week double-blind treatment with escitalopram + ACS treatment $(n=127)$, placebo + ACS treatment $(n=128)$, or ACS treatment alone $(n=123)$. Peripheral blood collected at baseline revealed that any depressive diagnosis was associated with higher $B D N F$ methylation at CPG sites $-1,-5,-8$, and -9 , and a higher average $B D N F$ promoter methylation percentage. Those patients randomized to the escitalopram group had a higher remission rate $(51.9 \%)$ than those in the placebo group $(34.3 \%)(p=0.011)$. When comparing depression remitters versus non-remitters, there was no significant difference in $B D N F$ methylation percentages. However, within the escitalopram treatment group, a higher baseline BDNF exon VI methylation percentage was associated with higher rates of remission. In those patients in the placebo or medical treatment only groups, a higher BDNF methylation at $\mathrm{CpG}-1$ of exon VI and a higher percent methylation of exon VI predicted persistence of depression at the one year follow-up. However, in the escitalopram group, there was no significant association between higher $\mathrm{CpG}-1$ or global methylation and persistence of depression [57].

One study investigated the effect of antidepressants on methylation of H3K27 (histone H3, lysine 27) in male Canadians [58]. Trimethylation of H3K27 has been associated with repressed BDNF exon IV gene expression in a mouse model of depression [33]. Chen et al. 2011 measured BDNF exon IV expression and H3K27 trimethylation levels in post-mortem prefrontal cortex of MDD patients who had completed suicide with a history of, and toxicology positive for, antidepressants $(n=7)$, MDD subjects who completed suicide with no history of antidepressant use and negative antidepressant toxicology $(n=11)$, and control subjects with no psychiatric history $(n=9)$ [58]. Antidepressants taken by MDD patients included fluoxetine, venlafaxine, clomipramine, amitriptyline, citalopram, and doxepin. MDD subjects taking antidepressants had significantly lower H3K27 methylation than the MDD patients with no antidepressant treatment and controls. Additionally, antidepressants, regardless of medication class, increased BDNF IV expression above baseline levels. The study found no significant decrease in BDNF I, II, or III expression between MDD patients not treated with antidepressants and controls [58].

Lopez et al. 2013 also investigated H3K27 trimethylation of BDNF exon IV in a prospective study of twenty-five treatment-naïve MDD patients treated with citalopram for eight weeks [59]. Subjects were classified as responders or non-responders based on change in Hamilton Depression Rating Scale (HAM-D) score from baseline to eight weeks of treatment. Peripheral BDNF mRNA levels and $B D N F$ exon IV H3K27 trimethylation were measured both at baseline and eight weeks of treatment. Responders exhibited a significantly increased peripheral BNDF mRNA levels after eight weeks on citalopram, while non-responders did not. The combined group of patients showed decreased H3K27 trimethylation after eight weeks of citalopram treatment $(p<0.001)$, although this was mostly explained by the responders. In the non-responder group, there was no significant difference in H3K27 trimethylation after treatment $(p>0.05)$. The responder group had significantly decreased H3K27 methylation after eight weeks of citalopram treatment compared to the non-responders, but there was no significant pre-treatment difference between the responders and non-responders $(p>0.05)$. Total peripheral BDNF and H3K27 trimethylation were significantly negatively correlated $(\mathrm{r}=-0.86$; $p<0.0001)$. The study suggested that citalopram increases BDNF expression through alterations of H3K27 of the BDNF exon IV promoter [59].

\section{2. $M A O A$}

Monoamine oxidase A (MAO-A) is an enzyme responsible for metabolizing monoamine neurotransmitters, influencing the levels of monoamine neurotransmitters at the synapse [60]. It plays a role in mood, aggression [61], stress response [62], and brain development [63]. Table 2 summarizes the included studies of the relationship between $M A O A$ DNA methylation and antidepressant medications. Checknita et al. 2018 examined methylation of the $M A O A$ promoter in 114 young Swedish women with abuse histories compared to female controls [64]. Increased methylation of CpG-7/8 of MAOA occurred 
in women with active depression and lifetime use of psychotropic medication (stimulants, hypnotics, anxiolytics, antidepressants, and antipsychotics), but no significant differences in methylation occurred when lifetime antidepressant use alone was analyzed [64].

Table 2. Summaries of studies exploring relationship of antidepressants and MAOA DNA methylation.

\begin{tabular}{|c|c|c|c|c|}
\hline Reference & $\begin{array}{l}\text { Genomic } \\
\text { Region } \\
\text { Studied }\end{array}$ & Study Description & $\begin{array}{l}\text { Tissue } \\
\text { Examined }\end{array}$ & Findings \\
\hline $\begin{array}{l}\text { Checknita et al., } \\
2018 \text { [64] }\end{array}$ & $\begin{array}{l}\text { Exon I } \\
\text { promoter }\end{array}$ & $\begin{array}{l}\text { MAOA was genotyped and } \\
\text { methylation was measured via } \\
\text { bisulfite conversion with PCR in } \\
\text { Swedish women with and without } \\
\text { substance use disorders, comparing } \\
\text { those with and without a history of } \\
\text { childhood sexual and/or physical } \\
\text { abuse. }\end{array}$ & $\begin{array}{l}\text { Genomic DNA } \\
\text { extracted from } \\
\text { saliva }\end{array}$ & $\begin{array}{l}\text { - Among women with current depression, higher } \\
\text { methylation was associated with past or current use of any } \\
\text { medication (stimulants, hypnotics, anxiolytics, } \\
\text { antidepressants, or antipsychotics) at CpG 7/8. } \\
\text { - When antidepressants were considered alone, no } \\
\text { differences in methylation were found. }\end{array}$ \\
\hline $\begin{array}{l}\text { Domschke et al., } \\
2015 \text { [65] }\end{array}$ & $\begin{array}{l}\text { Forty-three } \\
\text { CpG sites } \\
\text { within exon I } \\
\text { promoter. }\end{array}$ & $\begin{array}{l}\text { Methylation of } M A O A \text { was measured } \\
\text { in peripheral blood of German MDD } \\
\text { patients. Clinical response to } 6 \text { weeks } \\
\text { of escitalopram was assessed by } \\
\text { intra-individual changes in } \\
\text { HAM-D-21 scores between weeks } 1 \\
\text { and } 6 .\end{array}$ & $\begin{array}{l}\text { Peripheral } \\
\text { blood }\end{array}$ & $\begin{array}{l}\text { - In females, overall methylation across all } 3 \text { amplicons and } \\
\text { single CpGs showed no association with intake of } \\
\text { medication (SSRI, SSRI + mirtazapine, antipsychotics, or } \\
\text { mood stabilizers). } \\
\text { - Average methylation across all CpGs showed no } \\
\text { association with response to escitalopram after } 6 \text { weeks } \\
\text { in females. } \\
\text { - Lower methylation at CpG-1 in Amplicon A and CpG-5 in } \\
\text { Amplicon B were nominally associated with worse } \\
\text { treatment response after } 6 \text { weeks of escitalopram in females. } \\
\text { - In males, neither average methylation across all sites nor } \\
\text { methylation status of individual CpG sites showed } \\
\text { association with response to escitalopram after } 6 \text { weeks. }\end{array}$ \\
\hline
\end{tabular}

Domschke et al. 2015 hypothesized that hypomethylated MAOA in MDD may increase MAOA expression and thereby increase degradation of monoamines, potentially predicting reduced response to monoaminergic mechanisms of antidepressants [65]. Methylation of forty-three $\mathrm{CpG}$ sites within the $M A O A$ regulatory and exon I/intron I regions was investigated in ninety-four MDD patients treated with escitalopram. Treatment response was assessed by intra-individual differences in HAM-D-21 scores between the first and sixth week. In males, methylation of amplicons A and B was universally either absent or very low and had no significant association with treatment response. In females, average methylation across all $\mathrm{CpG}$ sites showed no significant association with clinical response to escitalopram. However, two individual CpG sites (CpG-1 in amplicon A and CpG-5 in amplicon B) did show nominal association with treatment response ( $p=0.04$ and $p=0.009$, respectively). Lower methylation of these sites was associated with worse escitalopram response after six weeks. This trend was consistent with the group's original hypothesis, predicting that higher levels of MAO-A would lead to decreased efficacy of escitalopram [65].

\subsection{SLC6A4}

The serotonin transporter removes serotonin from the synapse to the presynaptic neuron for recycling, thus influencing the duration of action of serotonin at the synapse [66]. It is encoded by SLC6A4 which has been implicated in risk of depression following emotional trauma. A study of thirty-three subjects with MDD and thirty-six HC investigated the associations between SLC6A4 methylation and history of childhood abuse [67]. Increased methylation of the SLC6A4 promoter at CpG-11 and -12 was associated with SSRI administration compared to no antidepressants $(p=0.02)$ or dual-action antidepressants $(p=0.009)$. After controlling for age, childhood trauma, and hippocampal volume, use of SSRI predicted a greater DNA methylation at CpG-11 and -12, suggesting SSRIs may increase DNA methylation at these sites, although sample size between antidepressant groups was very small [67].

DNA methylation in a CpG-rich region of the SLC6A4 promoter was measured using peripheral blood samples of 108 Korean patients with MDD [68]. Methylation was measured before twelve weeks of naturalistic antidepressant treatment including amitriptyline, bupropion, escitalopram, fluoxetine, imipramine, mirtazapine, paroxetine, sertraline, and venlafaxine. Clinical outcomes were determined 
by comparison of baseline and post-treatment scores for depression, anxiety, social, and occupational functioning, disability, and quality of life. Lower average SLC6A4 methylation and lower CpG-2 methylation were weakly associated with less depression improvement after antidepressant treatment. Increased CpG-1 methylation was associated with less improvement in anxiety and functioning. However, after Bonferroni correction, the strength of these associations was lost [68].

Domschke et al. 2014 investigated SLC6A4 promoter methylation at nine CpG sites in PBMC from ninety-four MDD subjects treated with either escitalopram only $(n=61)$ or escitalopram and mirtazapine $(n=33)$. Forty subjects were co-medicated with antipsychotics and twenty-nine were co-medicated with mood stabilizers [69]. Clinical response was measured by inter-individual change in HAM-D-21 scores between the start and end of six weeks of escitalopram treatment. Patients with a lower average pre-treatment methylation of the nine $\mathrm{CpG}$ sites had impaired response to escitalopram compared to those patients with higher pre-treatment DNA methylation. Investigations of individual CpG sites, CpG-1 ( $p=0.048)$, CpG-2 $(p=0.002)$, and CpG-4 $(p=0.029)$, showed (nominally) significant trends that low methylation at these sites was associated with decreased treatment response compared to subjects with higher baseline methylation [69].

SLC6A4 promoter methylation was studied in twenty-eight MDD patients before and after eight weeks of antidepressant treatment and twenty-nine HC [70]. MDD patients were treated with a variety of antidepressants: Paroxetine, sertraline, escitalopram, mirtazapine, fluvoxamine, milnacipran, amitriptyline, and maprotiline. Pre-treatment, MDD patients had a significantly increased expression of the 5HTT protein compared to unaffected controls $(p<0.01)$ and expression levels significantly decreased post-treatment $(p<0.01)$. At baseline, decreased levels of methylation of CpG-3 and -5 were correlated with more severe depression symptoms $(\mathrm{r}=-0.41, p=0.003 ; \mathrm{r}=-0.38, p=0.004)$. Lower baseline ClpG-2 methylation of the SLC6A4 promoter was associated with increased clinical improvement in depression severity after eight weeks of treatment $(r=-0.40 ; p=0.04)$ [70].

Okada et al. 2014 measured DNA methylation rates in a CpG island of SLC6A4 in the peripheral blood of fifty Japanese MDD patients before and after six weeks of antidepressant therapy with paroxetine, fluvoxamine, or milnacipran, and in fifty HC [71]. They were unable to distinguish between healthy controls and unmedicated MDD, or medicated/unmedicated MDD based on DNA methylation rates. Therapeutic response was defined based on improvement ratios (IRs), calculated by (HAM-D pre-treatment-HAM-D after six week treatment)/HAM-D pre-treatment. They discovered a significant increase in CpG-3 methylation after six weeks of antidepressant treatment. Furthermore, pre-treatment CpG-3 methylation rate was significantly, positively correlated with IR in MDD patients. There was no correlation between methylation change at CpG-3 between pre- and post-treatment and IR. Results suggested that higher pre-treatment CpG-3 methylation may predict better response to antidepressants [71].

\subsection{SLC6A2}

SLC6A2 encodes a sodium:norepinephrine symporter responsible for presynaptically loading norepinephrine and maintaining norepinephrine homeostasis. Table 3 summarizes the studies relating DNA methylation of the neurotransmitter transporter genes and antidepressant medications. In MDD, panic disorder, and controls, there have been associations between SLC6A2 promoter methylation and physiological factors such as BMI, heart rate, diastolic blood pressure, and age [72]. In a subset of five MDD and four panic disorder patients, two CpG sites (14 and 15 in Region A) were significantly hypermethylated following three month treatment with SSRIs (citalopram, fluoxetine, or sertraline) compared to pre-treatment, although the authors reported the methodology did not permit reliability of results [72]. 
Table 3. Summaries of studies exploring relationship of antidepressants and DNA methylation of serotonin and norepinephrine transporter genes.

\begin{tabular}{|c|c|c|c|c|}
\hline Reference & Genomic Region Studied & Study Description & Tissue Examined & Findings \\
\hline $\begin{array}{l}\text { Booij et al., } \\
2015[67]\end{array}$ & $\begin{array}{l}\text { SLC6A4 } \\
\text { CpG sites } 5-15 \text { within the } \\
214-625 \text { bp regulatory } \\
\text { region upstream of the } \\
\text { promoter. }\end{array}$ & $\begin{array}{l}\text { Analysis of SLC6A4 methylation via pyrosequencing and } \\
\text { luciferase reporter vector; compared with SLC6A4 mRNA } \\
\text { expression in T cells via RT-PCR; compared between } \\
\text { healthy controls, childhood trauma, and MDD. }\end{array}$ & $\begin{array}{l}\text { Peripheral blood } \mathrm{T} \\
\text { cells and monocytes }\end{array}$ & $\begin{array}{l}\text { - SSRIs associated with increased methylation at CpG-11 and }-12 \\
\text { compared to no antidepressants or dual-acting antidepressants. } \\
\text { - SSRI use predicted increased methylation at CpG-11 and }-12 \text {. }\end{array}$ \\
\hline $\begin{array}{l}\text { Kang et al., } \\
2013 \text { [68] }\end{array}$ & $\begin{array}{l}\text { SLC6A4 } \\
\text { CpG-rich region of the } \\
\text { promoter between - }-479 \text { and } \\
-350 \text { relative to the } \\
\text { transcriptional start site, } \\
\text { including } 7 \text { CpG sites. }\end{array}$ & $\begin{array}{l}\text { Measured DNA methylation of SLC6A4 in Korean MDD } \\
\text { patients. Patients were treated with a variety of } \\
\text { antidepressants for } 12 \text { weeks and clinical outcome was } \\
\text { measured by scales for depression, anxiety, functioning, } \\
\text { disability, and quality of life before and after } 12 \text { weeks of } \\
\text { antidepressant treatment. }\end{array}$ & Peripheral blood & $\begin{array}{l}\text { - Higher methylation at CpG-2 and higher average SLC6A4 methylation } \\
\text { predicted less HAM-D improvement in depression. } \\
\text { - Higher methylation percentage at CpG-1 was associated with less } \\
\text { improvement in HAM-A }{ }^{1} \text {. } \\
\text { • Higher average promoter methylation was associated with } \\
\text { decreased SOFAS }{ }^{2} \text {. } \\
\text { - All above findings lost significance after Bonferroni correction. }\end{array}$ \\
\hline $\begin{array}{l}\text { Domschke et al., } \\
2014 \text { [69] }\end{array}$ & $\begin{array}{l}\text { SLC6A4 } \\
\text { Nine CpG sites within the } \\
\text { transcriptional control } \\
\text { region upstream of exon 1A. }\end{array}$ & $\begin{array}{l}\text { Analyzed blood sample DNA methylation status in } \\
\text { Caucasian MDD patients. Clinical response to } 6 \text { weeks of } \\
\text { escitalopram treatment was assessed by intra-individual } \\
\text { changes in HAM-D-21 scores. }\end{array}$ & Peripheral blood & $\begin{array}{l}\text { - Overall SLC6A4 methylation in the analyzed amplicon showed no } \\
\text { association with medication intake (SSRI vs. SSRI + mirtazapine), or } \\
\text { comedication with antipsychotics or mood stabilizers. } \\
\text { - Average methylation across } 9 \text { CpG sites was significantly associated } \\
\text { with response to escitalopram after } 6 \text { weeks: Lower methylation was } \\
\text { associated with impaired treatment response, while higher methylation } \\
\text { was associated with better treatment response. } \\
\text { - Average methylation across CpGs post-treatment showed a nominally } \\
\text { significant association between lower methylation status and impaired } \\
\text { treatment response. } \\
\text { - Methylation status of individual CpG-1 and -2 were significantly } \\
\text { associated with treatment response after } 6 \text { weeks. CpG-4 methylation } \\
\text { was nominally associated with treatment response. }\end{array}$ \\
\hline $\begin{array}{l}\text { Iga, et al., } \\
2016[70]\end{array}$ & $\begin{array}{l}\text { SLC6A4 } \\
\text { One CpG-rich region in the } \\
\text { promoter, including } 9 \mathrm{CpG} \\
\text { sites. }\end{array}$ & $\begin{array}{l}\text { Measured DNA methylation in peripheral blood of } \\
\text { Japanese MDD patients before and after } 8 \text { weeks of } \\
\text { treatment with various antidepressants. Clinical outcome } \\
\text { was assessed with HAM-D. }\end{array}$ & Peripheral blood & $\begin{array}{l}\text { Lower CpG-2 methylation levels were associated with greater clinical } \\
\text { improvement as assessed by HAM-D scores. }\end{array}$ \\
\hline $\begin{array}{l}\text { Okada et al., } \\
2014 \text { [71] }\end{array}$ & $\begin{array}{l}\text { SLC6A4 } \\
\text { CpG island in exon I } \\
\text { promoter - sequence chr 17: } \\
28562388-28563186\end{array}$ & $\begin{array}{l}\text { Measured DNA methylation and responses to } \\
\text { antidepressant therapy in unmedicated, Japanese MDD } \\
\text { patients. }\end{array}$ & Peripheral blood & $\begin{array}{l}\text { - A significant increase in methylation was found in } \mathrm{CpG}-3 \text { after } 6 \text { weeks } \\
\text { of antidepressant treatment in MDD. } \\
\text { - Pre-treatment methylation of } \mathrm{CpG}-3 \text { showed significant positive } \\
\text { correlation with IR }{ }^{3} \text { in MDD. } \\
\bullet \text { No significant difference in methylation rates between the patients } \\
\text { with }>50 \% \text { IR and }<50 \% \text { IR. } \\
\bullet \text { No correlation between IR and methylation change of CpG-3 before } \\
\text { and after antidepressant treatment. }\end{array}$ \\
\hline $\begin{array}{l}\text { Bayles et al., } \\
2013[72]\end{array}$ & $\begin{array}{l}S L C 6 A 2 \\
\text { Promoter region } 1(-515 \mathrm{bp} \\
\text { to }-225 \mathrm{bp}), \text { promoter } \\
\text { region } 2(-180 \mathrm{bp}-+167 \mathrm{bp}), \\
\text { region } \mathrm{A} \text {, and region } \mathrm{B} \text {. }\end{array}$ & $\begin{array}{l}\text { Study of } S L C 6 A 2 \text { methylation using EpiTYPER assays in } \\
\text { an Australian population of MDD, panic disorder, and } \\
\text { healthy controls. } \\
\text { Subset comparison of SLC6A2 promoter methylation } \\
\text { before and after } 3 \text { month treatment with SSRIs in MDD } \\
\text { and panic disorder. }\end{array}$ & $\begin{array}{l}\text { Peripheral blood } \\
\text { leukocytes }\end{array}$ & $\begin{array}{l}\text { Statistically significant increase in methylation of CpG sites } 14 \text { and } 15 \\
\text { (Region A) in MDD and panic disorder patients after } 3 \text { months of } \\
\text { SSRI treatment. }\end{array}$ \\
\hline
\end{tabular}

${ }^{1}$ HAM-A, Hamilton Anxiety Rating Scale; ${ }^{2}$ SOFAS, Social and Occupational Functioning Assessment Score; ${ }^{3}$ IR, improvement ratio. 


\subsection{HTR1A/1B}

Serotonin receptor 5HT1A subtype variants have been associated with MDD and response to antidepressant treatment [73]. 5HT1A subtypes serve as serotonin autoreceptors and are involved in neuromodulation [74]. The 5HT1A receptor also has endocrine function, as agonism with ipsapirone promotes secretion of adrenocorticotrophin, cortisol, and growth hormone in humans [75]. 5HT1B has been associated with serotonin synthesis and influences behavior and anxiety in animal models [76]. Table 4 summarizes the studies of the relationship between DNA methylation of the serotonin receptor genes and antidepressant medications. After eight weeks of treatment with escitalopram in eighty-five Chinese Han MDD patients, analysis of a subset of 44 subjects showed that average methylation across HTR1A and HTR1B promoters did not significantly change [77]. However, four individual CpG sites demonstrated decreased methylation after treatment: HTR1B_1 amplicon CpG-336, HTR1B_2 amplicon CpG-105, HTR1B_2 amplicon CpG-107, and HTR1B_4 amplicon 1443. They extended the analysis to patients who remitted following the eight week treatment and found that remitters had increased methylation at six other CpG sites within $H T R 1 A / 1 B$ promoters (HTR1A_2 amplicon CpG-2793, HTR1A_2 amplicon CpG-2834, HTR1A_2 amplicon CpG-2927, HTR1A_2 amplicon CpG-2937, HTR1B_2 amplicon CpG-100, HTR1B_4 amplicon CpG-1401) [77].

HTR1A and HTR1B promoter methylation partially predicted response to antidepressant treatment. Average level of methylation of HTR1A or HTR1B in PBMC of depressed patients was not predictive of response to eight weeks of escitalopram treatment, but low pre-treatment methylation levels at CpG 668 ( $p=0.025)$, and CpG-1401 ( $p=0.033)$ significantly predicted poor treatment response. An interaction was also discovered between Life Event Score (LES), methylation of four specific CpG sites (HTR1A_1 CpG-659, CpG-668, and CpG-706, and HTR1B_2 CpG-107), and response to escitalopram. Individuals with low LES scores and higher $\mathrm{CpG}$ methylation responded better to escitalopram than those with higher LES scores and lower DNA methylation [77].

Gassó et al. 2017 studied HTR1B promoter methylation in eighty-three child and adolescent subjects treated for 12 weeks with fluoxetine for $\operatorname{MDD}(n=57)$, obsessive compulsive disorder $(n=16)$, and generalized anxiety disorder $(n=10)$ [78]. Lower HTR1B promoter methylation after treatment was associated with increased psychosocial functioning [78].

\subsection{IL6 and IL11}

Chronic inflammation of the CNS is associated with MDD [79] Altered levels of pro- and anti-inflammatory cytokine levels and the transcription factors that regulate them have been detected in patients with MDD [80]. The cytokine IL-6 is increased in patients with MDD compared to healthy controls [81]. Table 5 summarizes studies of the relationship between DNA methylation of cytokine genes and antidepressant medication use. Ryan et al. 2017 compared methylation of the IL6 gene in buccal cells from $92>65$-year-old subjects with and without MDD/high depressive symptoms and 288 HC [82]. Depression was associated with decreased IL6 methylation compared to controls, while antidepressant use was associated with an increase. Over half of MDD subjects took antidepressants in the SSRI class [82]. Another study conversely observed decreased IL-6 levels after antidepressant treatment [83].

Results from the Genome-based Therapeutic Drugs for Depression Project (GENDEP) identified a single nucleotide polymorphism (SNP) in the cytokine IL11 gene that predicted response to escitalopram [84]. IL11 promoter methylation not only predicted response to antidepressants, but also to specific medications. Powell et al. 2013 studied DNA methylation of the IL11 promoter in whole blood from 113 patients with moderate to severe MDD enrolled in GENDEP [85]. Patients were "partially randomized" to either twelve weeks of escitalopram $(n=80)$ or nortriptyline $(n=33)$ and baseline IL11 promoter methylation was measured. Depression severity was scored weekly by Montgomery-Asberg Depression Rating Scale (MADRS). Lower baseline methylation levels of CpG-5 predicted better response to both antidepressants $(p=0.005)$, while higher methylation of CpG-4 was associated with better response to escitalopram, but lower response to nortriptyline $(p=0.005)$. Lastly, 
individuals homozygous for the G allele (GG) of the SNP rs1126757 had higher levels of methylation at CpG-11 and better response to antidepressant treatment than those homozygous for the A allele (AA). There was no significant interaction between DNA methylation, the heterozygous genotype (AG), and response to antidepressants [85].

\subsection{Global DNA Methylation}

Takeuchi et al. 2017 examined genome-wide methylation in sixty-eight Japanese MDD patients treated with six weeks of paroxetine [86]. HAM-D-21 was used to assess psychological and physiological condition of patients at baseline, and weeks two, four, and six after paroxetine administration began. Two comparison groups were formed: The ten patients with the best response (BR) and worst response (WR) in HAM-D-21 scores. Comparing the BR and WR, HM450 DNA methylation analysis revealed 623 differentially methylated sites and 218 of them were nominally significantly different between BR and WR $(p<0.05)$. Two CpG sites were significantly differentially methylated: cg00594917 in the first exon PPFIA4 which codes for liprin- $\alpha(p=0.00012)$ and cg07260927 in the $5^{\prime}$ untranslated region of heparan sulfate-glucosamine 3-sulfotransferase 1 (HS3ST1) $(p=0.00013)$. Liprin proteins assist presynaptic neural transmission and interact with glutamate and muscarinic acetylcholine receptors. HS3ST1 encodes the rate-limiting enzyme for heparan biosynthesis and has not previously been associated with the mechanism of action of paroxetine or neural signaling. Hierarchical cluster analysis within PPFIA4 and HS3ST1 distinguished most treatment responders. At all six CpGs of PPFIA4, the WR group was hypermethylated compared to the BR group. Similarly, five CpG sites in HS3ST1 were differentially methylated between BR and WR [86].

Global DNA methylation patterns and methylation at certain sites correlate with biological age in humans [87]. This "epigenetic aging" was studied in 160 male combat-exposed veterans to investigate whether there was a difference in epigenetic age between subjects with and without post-traumatic stress disorder (PTSD) $(n=79 ; n=81)$ [88]. Verhoeven et al. 2018 discovered that PTSD subjects counterintuitively had a younger epigenetic age than subjects without PTSD. Subjects taking antidepressants had a lower epigenetic age than those without antidepressants regardless of PTSD diagnosis $(p=0.017)$. Subjects with PTSD + antidepressant had reduced epigenetic age compared to healthy subjects. However, using the Sobel method, authors calculated that antidepressant use was not a statistically significant mediator of the association between change in epigenetic age and PTSD status. It remains unclear whether the association of antidepressants and lower epigenetic age was due to the medications themselves or differences in diagnosis severity, since patients who used antidepressants had higher rates of MDD and higher PTSD/depression scores $(p<0.001)$ [88]. Table 6 summarizes included studies relating global DNA methylation and use of antidepressant medications. 
Table 4. Summaries of studies exploring relationship of antidepressants and DNA methylation of serotonin receptor genes.

\begin{tabular}{|c|c|c|c|c|}
\hline Reference & Genomic Region Studied & Study Description & Tissue Examined & Findings \\
\hline $\begin{array}{l}\text { Wang et al., } \\
2018 \text { [77] }\end{array}$ & $\begin{array}{l}H T R 1 A \text { and } H T R 1 B \\
\text { Ninety-six CpG sites within } \\
\text { promoter regions. }\end{array}$ & $\begin{array}{l}\text { Measured DNA methylation via PCR amplification of } \\
\text { bisulfate-converted DNA, in Han Chinese MDD patients } \\
\text { before and after } 8 \text { week treatment with escitalopram } \\
10-20 \text { mg daily. }\end{array}$ & $\begin{array}{l}\text { Whole blood } \\
\text { genomic DNA } \\
\text { isolate }\end{array}$ & 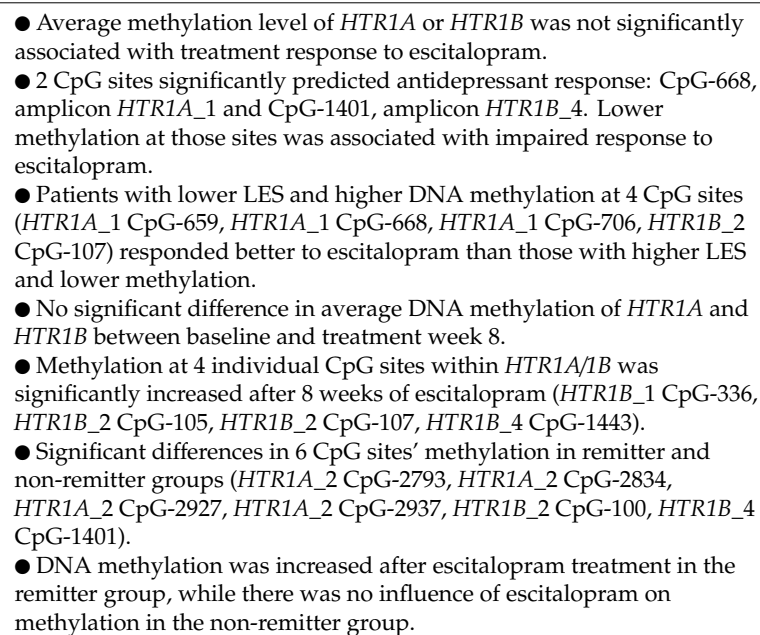 \\
\hline $\begin{array}{l}\text { Gassó et al., } \\
2017 \text { [78] }\end{array}$ & $\begin{array}{l}\text { HTR1B } \\
\text { CpG islands in promoter, } \\
\text { including } 7 \text { CpG sites. } \\
\text { Chromosome 6: } \\
\text { (77463994 - 77464019) }\end{array}$ & $\begin{array}{l}\text { Measured DNA methylation after Spanish children with } \\
\text { MDD, OCD } D^{1} \text { or } \mathrm{GAD}^{2} \text { completed } 12 \text { weeks of fluoxetine } \\
\text { treatment for the first time and assessed whether DNA } \\
\text { methylation was associated with clinical response to } \\
\text { fluoxetine. }\end{array}$ & Peripheral blood & $\begin{array}{l}\text { Negative correlation between average DNA methylation of the } 7 \mathrm{CpGs} \\
\text { analyzed in the } H T R 1 B \text { promoter and clinical response to fluoxetine as } \\
\text { measured by } \mathrm{GAF}^{3} / \mathrm{CGAS}^{4} \text {. }\end{array}$ \\
\hline
\end{tabular}

${ }^{1}$ OCD, obsessive compulsive disorder; ${ }^{2}$ GAD, generalized anxiety disorder; ${ }^{3}$ GAF, Global Assessment of Functioning Scale; ${ }^{4}$ CGAS, Children's Global Assessment Scale. 
Table 5. Summaries of studies exploring relationship of antidepressants and DNA methylation of cytokine genes.

\begin{tabular}{|c|c|c|c|c|}
\hline Reference & Genomic Region Studied & Study Description & Tissue Examined & Findings \\
\hline $\begin{array}{l}\text { Ryan et al., } \\
2017 \text { [82] }\end{array}$ & $\begin{array}{l}\text { IL6 } \\
234 \text { bp region of the } \\
\text { promoter }\end{array}$ & $\begin{array}{l}\text { Measured DNA methylation of IL6 in peripheral tissue of } \\
\text { French patients }>65 \text {-years-old with and without } \\
\text { depression, and with and without antidepressant } \\
\text { treatment. }\end{array}$ & Buccal swabs & $\begin{array}{l}\text { - Depression was associated with a } 2.4 \% \text { decreased overall IL6 } \\
\text { methylation compared to controls. } \\
\text { • Antidepressant use was associated with a mean } 4.6 \% \text { increase in } \\
\text { methylation of IL6. }\end{array}$ \\
\hline $\begin{array}{l}\text { Powell et al., } \\
2013 \text { [85] }\end{array}$ & $\begin{array}{l}\text { IL11 } \\
\text { CpG island in the promoter } \\
\text { (chr 19: 55880511-55880989) }\end{array}$ & $\begin{array}{l}\text { Measured baseline DNA methylation the IL11 promoter in } \\
\text { peripheral blood of Caucasian European MDD patients } \\
\text { randomized to } 12 \text { weeks of either escitalopram or } \\
\text { nortriptyline. }\end{array}$ & $\begin{array}{l}\text { Whole blood } \\
\text { genomic DNA } \\
\text { isolate }\end{array}$ & $\begin{array}{l}\text { - Methylation of CpG-5 predicted response to either antidepressant. } \\
\text { - Lower baseline CpG-5 methylation was associated with better } \\
\text { antidepressant response. } \\
\text { - CpG-4 methylation predicted differential response to the two } \\
\text { medications: High methylation levels were associated with better } \\
\text { response to escitalopram, but with worse response to nortriptyline. } \\
\text { • Methylation at CpG-11 and rs1126757 significantly predicted response } \\
\text { to treatment: Homozygous G allele (GG) individuals who had higher } \\
\text { levels of CpG-11 methylation responded better to antidepressant } \\
\text { treatment than those who were homozygous for the A allele (AA). }\end{array}$ \\
\hline
\end{tabular}

Table 6. Summaries of studies exploring relationship of antidepressants and whole genome DNA methylation.

\begin{tabular}{|c|c|c|c|c|}
\hline Reference & Genomic Region Studied & Study Description & Tissue Examined & Findings \\
\hline $\begin{array}{l}\text { Takeuchi et al., } \\
2017 \text { [86] }\end{array}$ & Whole genome & $\begin{array}{l}\text { Measured genome-wide methylation in peripheral blood } \\
\text { cells of MDD patients before } 6 \text { week treatment with } \\
\text { paroxetine. Compared the patients who were the best and } \\
\text { worst responders to paroxetine. }\end{array}$ & $\begin{array}{l}\text { Whole blood } \\
\text { genomic DNA } \\
\text { isolate }\end{array}$ & $\begin{array}{l}\text { - } 623 \text { CpG sites had a }>10 \% \text { difference in methylation status between the } \\
\text { best (BR) and worst (WR) responders to paroxetine, with } 218 \text { sites } \\
\text { nominally significantly different and } 2 \text { sites significantly different: } \\
\text { cg00594917 (PPFIA4 exon I) and cg07260927 (in the } 5^{\prime} \text { UTR of HS3ST1). } \\
\text { - Methylation difference between WR and BR was greatest at cg00594917 } \\
\text { in PPFIA4 exon I. } \\
\text { • Hierarchical cluster analysis of } 23 \text { CpG sites in PPFIA4 distinguished } \\
\text { BR and WR patients except for } 1 \text { patient. } \\
\text { - Methylation of } 6 \text { CpG sites within PPFIA4 was significantly different } \\
\text { between BR and WR. At all } 6 \text { sites, WR had higher methylation than BR } \\
\text { • Hierarchical cluster analysis of } 28 \text { CpG sites in HS3ST1 distinguished } \\
\text { BR and WR patients except for } 1 \text { patient. } \\
\text { • Methylation of } 5 \text { CpG sites within HS3ST1 was significantly different } \\
\text { between WR and BR. At } 4 \text { of } 5 \text { sites, methylation levels of WR were } \\
\text { higher than those of BR. }\end{array}$ \\
\hline $\begin{array}{l}\text { Verhoeven et al., } \\
2018 \text { [88] }\end{array}$ & Whole genome & $\begin{array}{l}\text { Applied Horvath's epigenetic clock algorithm to calculate } \\
\text { epigenetic age of leukocyte genomes of combat-exposed } \\
\text { veterans with and without PTSD. }\end{array}$ & PBMC & $\begin{array}{l}\text { - Current antidepressant use was associated with lower epigenetic age } \\
\text { in veterans across the sample compared to subjects not taking } \\
\text { antidepressants. } \\
\text { - PTSD subjects taking antidepressants had a significantly lower } \\
\text { epigenetic age than participants without PTSD. }\end{array}$ \\
\hline
\end{tabular}




\section{Discussion}

Multiple studies have suggested that DNA methylation in humans can be altered by antidepressants and promote mood symptom remission. Additionally, pre-treatment DNA methylation profiles of certain genes may predict an individual's likelihood of achieving remission, allowing clinicians to personalize and optimize treatment. The interaction between DNA methylation and antidepressants has been studied in cell lines, animals, and humans via global DNA methylation and specific genes.

The epigenetic effects of antidepressants on the BDNF gene are the best studied, but the results remain difficult to interpret. The neurotrophic hypothesis of depression posits that depression should be associated with decreased $B D N F$ expression [89], potentially driven by $B D N F$ hypermethylation. However, four studies reported antidepressant use associated with hypermethylation of the BDNF promoter [49-52]. D'Addario et al.'s 2012 study explored bipolar subtypes and found higher methylation in BD2, a subtype which may present with more depressive episodes than BD1, although this was not explicitly explored in the paper [49]. However, the finding that higher levels of DNA methylation were observed in subjects on pharmacological treatment with mood stabilizers plus antidepressants compared to mood stabilizers alone is more complicated; it may reflect antidepressants being used in subjects with more frequent depressive episodes, increased depressive severity, or treatment resistance. More confusing was the Carlberg et al. 2014 finding that hypermethylation was significantly associated with antidepressant therapy but not depression severity [51]. To tease apart these questions would require a study of $B D N F$ methylation of subjects with acute and chronic depressive episodes, at baseline, during treatment, after depression remission, and after antidepressant cessation.

Studies have shown that early increases in serum and plasma BDNF levels within the first seven to fourteen days of starting an antidepressant medication may predict improvement in MDD symptoms after six weeks of treatment $[56,90]$. Counterintuitively, a pre-treatment hypomethylated BDNF promoter has been associated with poor antidepressant response [52,55]. Perhaps antidepressants increase BDNF expression through a mechanism other than decreasing methylation of the BDNF promoter, such as by decreasing H3K27 methylation in BDNF exon IV. Studies of H3K27 methylation of the BDNF exon IV promoter highlight the consistency of methylation changes across PBMC and postmortem prefrontal cortex samples. Lopez et al. 2013 confirmed that antidepressant treatment decreased H3K27 methylation in PBMC [59], as Chen et al. 2011 also demonstrated decreased H3K27 methylation in postmortem prefrontal cortex samples from MDD subjects who were taking antidepressants [58]. Antidepressants' effects on histone modifications may be more important in increasing BDNF expression than DNA methylation of the promoter. BDNF promoter hypomethylation predicted poor response to antidepressant treatment [52,55], but corresponded with greater improvement in suicidality in a separate study [54]. However, increased BDNF promoter methylation after antidepressant treatment correlated with depression remission [52,57].

Kim et al. 2015 hypothesized that antidepressants may be more active on BDNF that is hypermethylated because $B D N F$ methylation may be required for binding of methyl-CpG-binding protein 2 (MECP2) [57]. One of the proposed mechanisms for antidepressant action increasing $B D N F$ expression is through phosphorylation of MECP2 and subsequent dissociation of MECP2 from DNA. Kim et al. 2015 found that depression persistence was associated with higher baseline BDNF methylation only in the placebo or medical treatment only group but not in the escitalopram group. They postulated that escitalopram caused MECP2 to dissociate from DNA, preventing depression persistence [57]. Tadić et al. 2014 made the same argument about the requirement of DNA methylation for MECP2 binding regarding their observation that lack of methylation at CpG-87 in the BDNF exon IV promoter was associated with non-response to treatment and a decrease in peripheral BDNF [55].

Analysis of buccal-derived DNA reported that MDD in elderly patients was associated with hypermethylated $B D N F$ promoters, with no effect of antidepressant treatment [53]. This finding of hypermethylated BDNF is consistent with most studies of methylation status of BDNF in MDD or other depressive disorders [91]. Whether this reflected treatment-resistance, severity, or an age-related 
effect is unclear. It is also important to consider that different tissues as well as different regions within the CNS have different methylation profiles [92]. Which better reflects the methylation status of the CNS with regard to BDNF methylation remains to be discovered because the blood and buccal tissue types are almost equally concordant with the brain [93].

In light of the monoamine hypothesis of depression, investigators have studied MAOA DNA methylation and its interaction with antidepressants. The enzyme product of $M A O A$ breaks down the same monoamines increased at the synapse by SSRIs. Checknita et al. 2018 did not find a significant effect of antidepressants on $M A O A$ methylation in saliva, but it is unclear how well the DNA methylation in heterogeneous saliva cell samples correlates to cells of the CNS [64]. Domschke et al. 2015 found a nominal association between 2 CpG sites within MAOA and response to escitalopram [65]. They discovered that hypomethylation of $M A O A$ led to worse response to antidepressant medications. They hypothesized that this was due to increased MAO-A available to counteract the effect of SSRIs. Interestingly, $M A O A$ often fails to escape $\mathrm{X}$-inactivation, putting females at increased risk of excessively high MAO-A levels and consequently deficient levels of serotonin and norepinephrine. These two studies alone do not provide enough evidence that $M A O A$ promoter methylation plays an important role in antidepressant action or treatment response. Future studies could consider measuring MAO-A protein levels in patients with hyper- and hypo-methylated MAOA and measure response to an MAO-I class antidepressant [65]. One obstacle to this type of study is that MAO-I antidepressants are rarely used clinically due to their side effect and safety profile, and animal models may be required instead.

Investigators also studied SLC6A4, a serotonin transporter responsible for removal of serotonin from the synapse, as decreased expression of this gene could lead to more serotonin in the synapse, but less serotonin recycling. Booij et al. 2015 discovered that SSRIs increase promoter methylation at CpG-11 and -12 when compared to no antidepressants or non-SSRI antidepressants [67]. This suggests that the methylation of the SLC6A4 gene may be a mechanism unique to SSRIs. Okada et al. 2014 discovered a significant increase in CPG-3 methylation after six weeks of treatment with either SSRI or SNRI [71]. Domschke et al. 2014 discovered a significant association between low promoter SLC6A4 methylation and impaired response to escitalopram [69]. Similarly, Iga et al. 2016 discovered that decreased levels of CpG-3 and CpG-5 methylation were associated with more severe depression and increased CpG-2 methylation was associated with increased clinical improvement with treatment [70]. Higher pre-treatment methylation of CpG-3 likewise correlated with increased improvement in clinical symptoms of depression [71]. Based on these studies, SLC6A4 methylation appears to be increased by antidepressants and increased promoter methylation is predictive of better treatment response.

Methylation status of specific CpG sites within HTR1A and HTR1B predicted treatment response, as shown by Wang et al.'s 2018 finding that methylation of certain $\mathrm{CpG}$ sites only increased in the subjects who remitted from their depression [77]. This may reveal one of the mechanisms of action of escitalopram in treating depressive symptoms, potentially decreasing expression of these serotonin transporters and potentiating serotonin in the synapse. Gassó et al. 2017 found that lower pre-treatment average HTR1B promoter methylation is associated with increased patient functioning after fluoxetine treatment [78]. Their hypothesis was that patients with lower pre-treatment methylation had high HTR1B expression and lower serotonin, so they were able to gain more clinical improvement from fluoxetine than those with lower initial HTR1B expression.

Studies of cytokines have also provided insight into potential mechanisms of antidepressants in reducing inflammation. For example, Ryan et al. 2017 showed an increase in methylation of the IL6 promoter with antidepressant use which could presumably lower IL-6 levels [82]. Additionally, Powell et al. 2013 presented how differential methylation of the IL11 gene could distinguish between better treatment options for individuals: Subjects with hypermethylated CpG-4 responded better to escitalopram, while those with hypomethylation responded better to nortriptyline [85]. IL-11, along with other cytokines like TNF- $\alpha$ and IL-6, has been shown to interfere with serotonin signaling [94]. These studies implicate cytokines as potential targets for novel antidepressants. Differences in DNA methylation at certain $\mathrm{CpG}$ sites can serve as guides for clinicians to choose the optimal medication. 
Examining the effect of antidepressants on the global methylome yielded discoveries of two genes that are differentially methylated in patients who were the worst and best responders to paroxetine [86]. Takeuchi et al. 2017 identified PPFIA4 and HSG3ST1 as genes of future investigation related to antidepressant mechanism and response. The methylation status of certain $\mathrm{CpG}$ sites within these genes could explain individual variability in response to paroxetine treatment [86]. Verhoeven et al.'s 2018 study of veterans with and without PTSD introduced the idea that antidepressant medications may have a global effect on DNA methylation patterns that alter one's epigenetic age [88]. The long-term effects of these medications on not only depression but general medical health are yet to be explored [88].

The results of studies investigating the relationship between antidepressant medications and DNA methylation can be difficult to compare due to the different genes, tissues, and CpG sites examined in each experiment. There are countless approaches to measure subjects' response to antidepressants, including scales of depression severity, functional level, suicidality, residual symptoms, and number of failed antidepressant trials [86]. Furthermore, the articles in our review often studied distinct populations that prevent generalizability of the results, such as combat-exposed male veterans [88] or females who had experienced physical and/or sexual abuse [64]. Methylation profiles of these samples may be affected by life experiences, comorbid anxiety disorders [65], or age [95]. As these were all studies of human subjects, researchers could not ensure medication compliance or select patients who were taking a single class of antidepressant medication [58]. Because many of these were naturalistic studies, there was no way to standardize antidepressant dosing regimens or confirm whether antidepressant dose affects DNA methylation [52].

Further investigation into the relationship between antidepressants and DNA methylation is warranted, as these preliminary studies used relatively small sample sizes. Researchers have been able to detect $\mathrm{CPG}$ sites significantly associated with antidepressant response or non-response, but it is still unclear whether these differences are biologically and clinically meaningful [85]. Although blood, buccal cell, and saliva have been accepted as reasonable surrogates for DNA methylation in the brain, future studies should also explore the effect of antidepressants on DNA methylation in the brain $[49,51]$. It will be important to conduct randomized, controlled trials to distinguish the effect of pharmacologic treatment on DNA methylation from the effect of the MDD phenotype itself [51]. As MDD can be a chronic condition, there are also opportunities to study the change in DNA methylation longitudinally over years in genes such as BDNF or IL6 and investigate whether DNA methylation is dynamically linked to incidence, severity, and remission from MDD [53,82]. Furthermore, analysis of global DNA methylation has already implicated genes like HSG3TS1 that were not previously associated with neural signaling as potential players in MDD pathogenesis and antidepressant response [86].

\section{Materials and Methods}

We conducted a comprehensive literature search of PubMed, PsycINFO, and SCOPUS from 24 January 1975 (discovery of transcriptional control by DNA methylation [96]) to 22 June 2019. Database-specific truncations were used. The search string was Title/Abstract/Keywords ("antidepressant" OR "anti-depressant" OR "SSRI" OR "selective serotonin reuptake inhibitor" OR "SNRI" OR "selective norepinephrine reuptake inhibitor" OR "MAO*" OR "bupropion" OR "tricyclic antidepressant" OR “TCA") AND ("epigen*") AND ("methylat"). Articles were collated in Endnote X9 (Clarivate Analytics, Philadelphia, PA). Duplicates were removed manually by the first author. Each abstract was reviewed independently by the first and second authors. Twenty-eight articles were selected for full text review (Figure 2). Inclusion criteria were: (1) Discussed the effect of antidepressant medications on DNA methylation in humans or the ability of DNA methylation to predict clinical response to antidepressant treatment in humans; (2) and full-text was available in English. Exclusion criteria were: (1) Studies that examined the effects of antidepressants on DNA methylation in utero (reviewed in Gentile and Fusco 2017 [97]). Each experimental paper was reviewed for design, sample size, description and duration of experiment, types of controls, collection of results, analysis, and 
findings. Data were extracted independently and in duplicate by the first and second authors. Studies were appraised for quality and risk of bias using a modified published process [98].

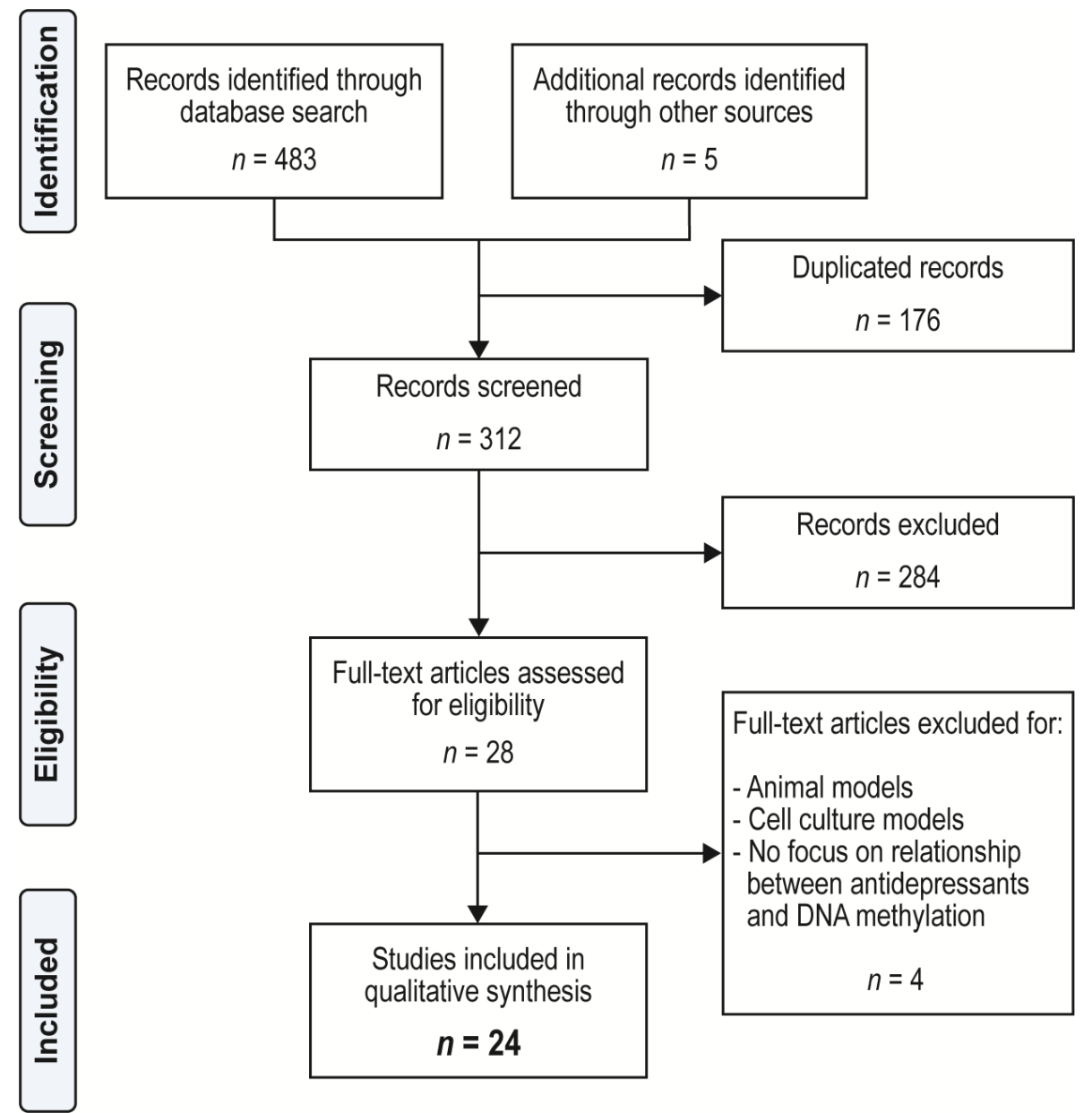

Figure 2. Preferred Reporting Items for Systematic Reviews and Meta-Analyses (PRISMA) flow diagram for systematic literature review [99]. Twenty-four articles met full inclusion criteria. The articles described the relationship between antidepressant administration and DNA methylation in the following genes: Brain-derived neurotrophic factor (BDNF) [49-55,57-59] (Table 1), monoamine oxidase A $(M A O A)$ [64,65] (Table 2), 5-hydroxytryptamine (serotonin) transporter (SLC6A4) [67-71] (Table 3), norepinephrine transporter (SLC6A2) [72] (Table 3), 5-hydroxytryptamine transporters 1A and 1B (5HTR1A/1B) [77,78] (Table 4), interleukin-6 (IL6) [82], and interleukin-11 (IL11) [85] (Table 5). Two papers reported antidepressant effects on global DNA methylation [86,88] (Table 6).

\section{Conclusions}

These studies demonstrate that epigenetic profiles have the potential to be used clinically to make decisions regarding antidepressant therapy. Choosing the best medication for a patient's unique epigenome could optimize treatment effectiveness and reduces the time spent suffering. Epigenomic profiling may eventually be undertaken routinely with pharmacogenomics as part of individualized treatment plans. However, translating the biochemical data into clinical guidelines will require further investigation of different antidepressant class effects on epigenetic signaling, and their correlation with treatment response in various disease phenotypes.

Author Contributions: Conceptualization, L.M.W., M.V., and C.J.B.; methodology, L.M.W. and C.J.B.; data curation, L.M.W., and K.E.P.; formal analysis L.M.W., K.E.P. and C.J.B.; investigation, L.M.W., and K.E.P.; project administration, C.J.B.; writing—original draft preparation, L.M.W., K.E.P. and C.J.B.; writing—review and editing, 
L.M.W., K.E.P., M.C.H., M.V. and C.J.B.; visualization C.J.B. and M.C.H., supervision, M.V. and C.J.B; funding acquisition, M.V. All authors have read and agreed to the published version of the manuscript.

Funding: This research received no external funding.

Conflicts of Interest: The authors declare no conflict of interest.

\section{Abbreviations}

\begin{tabular}{|c|c|}
\hline WHO & World Health Organization \\
\hline MDD & Major depressive disorder \\
\hline CpG & Cytosine-phosphate-guanine dinucleotides \\
\hline BDNF & Brain-derived neurotrophic factor \\
\hline PBMC & Peripheral blood mononuclear cells \\
\hline CNS & Central nervous system \\
\hline BD1 & Bipolar disorder type 1 \\
\hline BD2 & Bipolar disorder type 2 \\
\hline $\mathrm{HC}$ & Healthy controls \\
\hline SSRI & Selective serotonin reuptake inhibitor \\
\hline SNRI & Selective norepinephrine reuptake inhibitor \\
\hline TCA & Tricyclic antidepressant \\
\hline $\mathrm{BD}$ & Bipolar disorder \\
\hline SI & Suicidal ideation \\
\hline MAO-I & Monoamine-oxidase inhibitor \\
\hline ACS & Acute coronary syndrome \\
\hline Н3К27 & Histone $\mathrm{H} 3$, lysine 27 \\
\hline HAM-D & Hamilton Depression Rating Scale \\
\hline MAO-A & Monoamine oxidase A \\
\hline SLC6A4 & Serotonin transporter \\
\hline IR & Improvement ratio \\
\hline SLC6A2 & Sodium:norepinephrine symporter \\
\hline HTR1A & 5-hydroxytryptamine transporter $1 \mathrm{~A}$ \\
\hline HTR1B & 5-hydroxytryptamine transporter $1 \mathrm{~B}$ \\
\hline LES & Life Event Score \\
\hline IL6 & Interleukin-6 \\
\hline IL-11 & Interleukin-11 \\
\hline GENDEP & Genome-based Therapeutic Drugs for Depression Project \\
\hline MADRS & Montgomery-Asberg Depression Rating Scale \\
\hline $\mathrm{BR}$ & Best response \\
\hline WR & Worst response \\
\hline HS3ST1 & Heparan sulfate-glucosamine 3-sulfotransferase 1 \\
\hline PTSD & Post-traumatic stress disorder \\
\hline MECP2 & Methyl-CpG-binding protein 2 \\
\hline TNF- $\alpha$ & Tumor necrosis factor alpha \\
\hline PRISMA & Preferred Reporting Items for Systematic Reviews and M \\
\hline
\end{tabular}

\section{References}

1. World Health Organization. Depression and Other Common Mental Disorders Global Health Estimates; World Health Organization: Geneva, Switzerland, 2017; pp. 1-24.

2. Marcus, M.; Yasamy, M.T.; van Ommeren, M.; Chisholm, D.; Saxena, S. Depression A Global Public Health Concern; WHO Department of Mental Health and Substance Abuse. Available online: https://www. who.int/mental_health/management/depression/who_paper_depression_wfmh_2012.pdf (accessed on 27 January 2020).

3. Knol, M.J.; Twisk, J.W.; Beekman, A.T.; Heine, R.J.; Snoek, F.J.; Pouwer, F. Depression as a risk factor for the onset of type 2 diabetes mellitus. A meta-analysis. Diabetologia 2006, 49, 837-845. [CrossRef] [PubMed] 
4. Lett, H.S.; Blumenthal, J.A.; Babyak, M.A.; Sherwood, A.; Strauman, T.; Robins, C.; Newman, M.F. Depression as a risk factor for coronary artery disease: Evidence, mechanisms, and treatment. Psychosom. Med. 2004, 66, 305-315. [CrossRef] [PubMed]

5. Greenberg, P.E.; Kessler, R.C.; Birnbaum, H.G.; Leong, S.A.; Lowe, S.W.; Berglund, P.A.; Corey-Lisle, P.K. The Economic Burden of Depression in the United States: How Did It Change Between 1990 and 2000? J. Clin. Psychiatry 2003, 64, 1465-1475. [CrossRef] [PubMed]

6. Roser, M.; Ritchie, H.; Ortiz-Ospina, E. World Population Growth. Available online: https://ourworldindata. org/world-population-growth? (accessed on 27 January 2020).

7. World Health Organization. Mental Health and Older Adults. Geneva. Available online: https://www.who. int/news-room/fact-sheets/detail/mental-health-of-older-adults (accessed on 27 January 2020).

8. Sackeim, H.A. The Definition and Meaning of Treatment-Resistant Depression. J. Clin. Psychiatry 2001, 62, 10-17.

9. Berton, O.; Nestler, E.J. New approaches to antidepressant drug discovery: Beyond monoamines. Nat. Rev. Neurosci. 2006, 7, 137-151. [CrossRef]

10. Mathew, S.J.; Manji, H.K.; Charney, D.S. Novel Drugs and Therapeutic Targets for Severe Mood Disorders. Neuropsychopharmacology 2008, 33, 2080-2092. [CrossRef]

11. Hyman, S.E. Revitalizing Psychiatric Therapeutics. Neuropsychopharmacology 2014, 39, 220-229. [CrossRef]

12. Nestler, E.J. Antidepressant treatments in the 21st century. Biol. Psychiatry 1998, 44, 526-533. [CrossRef]

13. Wray, N.R.; Pergadia, M.L.; Blackwood, D.H.; Penninx, B.W.; Gordon, S.D.; Nyholt, D.R.; Ripke, S.; MacIntyre, D.J.; McGhee, K.A.; Maclean, A.W.; et al. Genome-wide association study of major depressive disorder: New results, meta-analysis, and lessons learned. Mol. Psychiatry 2012, 17, 36-48. [CrossRef]

14. Lisoway, A.J.; Zai, C.C.; Tiwari, A.K.; Kennedy, J.L. DNA methylation and clinical response to antidepressant medication in major depressive disorder: A review and recommendations. Neurosci. Lett. 2018, 669, 14-23. [CrossRef] [PubMed]

15. Fraga, M.F.; Ballestar, E.; Paz, M.F.; Ropero, S.; Setien, F.; Ballestar, M.L.; Heine-Suñer, D.; Cigudosa, J.C.; Urioste, M.; Benitez, J.; et al. Epigenetic differences arise during the lifetime of monozygotic twins. Proc. Natl. Acad. Sci. USA 2005, 102, 10604-10609. [CrossRef] [PubMed]

16. Kessler, R.C.; Bromet, E.J. The Epidemiology of Depression Across Cultures. Annu. Rev. Public Health 2013, 34, 119-138. [CrossRef] [PubMed]

17. Franklin, T.B.; Russig, H.; Weiss, I.C.; Gräff, J.; Linder, N.; Michalon, A.; Vizi, S.; Mansuy, I.M. Epigenetic Transmission of the Impact of Early Stress Across Generations. Biol. Psychiatry 2010, 68, 408-415. [CrossRef] [PubMed]

18. Nestler, E.J. Epigenetic Mechanisms of Depression. JAMA Psychiatry 2014, 71, 454-456. [CrossRef]

19. Roth, T.L.; Lubin, F.D.; Funk, A.J.; Sweatt, J.D. Lasting Epigenetic Influence of Early-Life Adversity on the BDNF Gene. Biol. Psychiatry 2009, 65, 760-769. [CrossRef]

20. Mitchell, A.C.; Bharadwaj, R.; Whittle, C.; Krueger, W.; Mirnics, K.; Hurd, Y.; Rasmussen, T.; Akbarian, S. The Genome In Three Dimensions: A New Fronteir in Human Brain Research. Biol. Psychiatry 2014, 75, 961-969. [CrossRef]

21. Merkl, A.; Neumann, W.J.; Huebl, J.; Aust, S.; Horn, A.; Krauss, J.K.; Dziobek, I.; Kuhn, J.; Schneider, G.H.; Bajbouj, M.; et al. Modulation of Beta-Band Activity in the Subgenual Anterior Cingulate Cortex during Emotional Empathy in Treatment-Resistant Depression. Cereb. Cortex 2016, 26, 2626-2638. [CrossRef]

22. Dolinoy, D.C.; Weidman, J.R.; Jirtle, R.L. Epigenetic gene regulation: Linking early developmental environment to adult disease. Reprod. Toxicol. 2007, 23, 297-307. [CrossRef]

23. Boks, M.P.; de Jong, N.M.; Kas, M.J.; Vinkers, C.H.; Fernandes, C.; Kahn, R.S.; Mill, J.; Ophoff, R.A. Current status and future prospects for epigenetic psychopharmacology. Epigenetics 2012, 7, 20-28. [CrossRef]

24. Ptak, C.; Petronis, A. Epigenetics and Complex Disease: From Etiology to New Therapeutics. Annu. Rev. Pharm. Toxicol. 2008, 48, 257-276. [CrossRef]

25. Wei, J.W.; Huang, K.; Yang, C.; Kang, C.S. Non-coding RNAs as regulators in epigenetics (Review). Oncol. Rep. 2017, 37, 3-9. [CrossRef] [PubMed]

26. Dalton, V.S.; Kolshus, E.; McLoughlin, D.M. Epigenetics and depression: Return of the repressed. J. Affect. Disord 2014, 155, 1-12. [CrossRef] [PubMed]

27. Szyf, M. Targeting DNA methylation in cancer. Bull. Cancer 2006, 93, 961-972. [CrossRef] 
28. Weber, M.; Schübeler, D. Genomic patterns of DNA methylation: Targets and function of an epigenetic mark. Curr. Opin. Cell Biol. 2007, 19, 273-280. [CrossRef] [PubMed]

29. Hervouet, E.; Vallette, F.M.; Cartron, P.F. Dnmt3/transcription factor interactions as crucial players in targeted DNA methylation. Epigenetics 2009, 4, 487-499. [CrossRef]

30. Putiri, E.L.; Robertson, K.D. Epigenetic mechanisms and genome stability. Clin. Epigenetics 2011, 2, $299-314$. [CrossRef]

31. Lister, R.; Mukamel, E.A. Turning over DNA methylation in the mind. Front. Neurosci. 2015, 9, 252. [CrossRef]

32. Alberini, C.M. The role of protein synthesis during the labile phases of memory: Revisiting the skepticism. Neurobiol. Learn. Mem. 2008, 89, 234-246. [CrossRef]

33. Tsankova, N.M.; Berton, O.; Renthal, W.; Kumar, A.; Neve, R.L.; Nestler, E.J. Sustained hippocampal chromatin regulation in a mouse model of depression and antidepressant action. Nat. Neurosci. 2006, 9, 519-525. [CrossRef]

34. Covington III, H.E.; Vialou, V.; Nestler, E.J. From synapse to nucleus: Novel targets for treating depression. Neuropharmacology 2010, 58, 683-693. [CrossRef]

35. Petronis, A. Epigenetics as a unifying principle in the aetiology of complex traits and diseases. Nature 2010, 465, 721-727. [CrossRef] [PubMed]

36. Nagy, C.; Vaillancourt, K.; Turecki, G. A role for activity-dependent epigenetics in the development and treatment of major depressive disorder. Genes Brain Behav. 2018, 17, e12446. [CrossRef] [PubMed]

37. Habano, W.; Kawamura, K.; Iizuka, N.; Terashima, J.; Sugai, T.; Ozawa, S. Analysis of DNA methylation landscape reveals the roles of DNA methylation in the regulation of drug metabolizing enzymes. Clin. Epigenetics 2015, 7, 105. [CrossRef] [PubMed]

38. Tiili, E.M.; Antikainen, M.S.; Mitiushkina, N.V.; Sukhovskaya, O.A.; Imyanitov, E.N.; Hirvonen, A.P. Effect of genotype and methylation of CYP2D6 on smoking behaviour. Pharm. Genom. 2015, 25, 531-540. [CrossRef] [PubMed]

39. Martinowich, K.; Manji, H.; Lu, B. New insights into BDNF function in depression and anxiety. Nat. Neurosci. 2007, 10, 1089-1093. [CrossRef] [PubMed]

40. Yu, H.; Chen, Z.Y. The role of BDNF in depression on the basis of its location in the neural circuitry. Acta Pharm. Sin. 2011, 32, 3-11. [CrossRef]

41. Rasmusson, A.M.; Shi, L.; Duman, R. Downregulation of BDNF mRNA in the Hippocampal Dentate Gyrus after Re-exposure to Cues Previously Associated with Footshock. Neuropsychopharmacology 2002, 27, $133-142$. [CrossRef]

42. Roceri, M.; Hendriks, W.; Racagni, G.; Ellenbroek, B.A.; Riva, M.A. Early maternal deprivation reduces the expression of BDNF and NMDA receptor subunits in rat hippocampus. Mol. Psychiatry 2002, 7, 609-616. [CrossRef]

43. Blaze, J.; Asok, A.; Borrelli, K.; Tulbert, C.; Bollinger, J.; Ronca, A.E.; Roth, T.L. Intrauterine exposure to maternal stress alters $B d n f I V$ DNA methylation and telomere length in the brain of adult rat offspring. Int. J. Dev. Neurosci. 2017, 62, 56-62. [CrossRef]

44. Duman, R.S. Pathophysiology of depression: The concept of synaptic plasticity. Eur. Psychiatry 2002, 17 (Suppl. 3), 306-310. [CrossRef]

45. Chen, B.; Dowlatshahi, D.; MacQueen, G.M.; Wang, J.F.; Young, L.T. Increased hippocampal bdnf immunoreactivity in subjects treated with antidepressant medication. Biol. Psychiatry 2001, 50, 260-265. [CrossRef]

46. Fujimura, H.; Altar, C.A.; Chen, R.; Nakamura, T.; Nakahashi, T.; Kambayashi, J.; Sun, B.; Tandon, N.N. Brain-derived Neurotrophic Factor is Stored in Human Platelets and Released by Agonist Stimulation. Thromb. Haemost. 2002, 87, 728-734. [CrossRef] [PubMed]

47. Rao, P.; Benito, E.; Fischer, A. MicroRNAs as biomarkers for CNS disease. Front. Mol. Neurosci. 2013, 6, 39. [CrossRef] [PubMed]

48. Sharma, R.P. Blood chromatin as a biosensor of the epigenetic milieu: A tool for studies in living psychiatric patients. Epigenomics 2012, 4, 551-559. [CrossRef] [PubMed]

49. D’Addario, C.; Dell'Osso, B.; Palazzo, M.C.; Benatti, B.; Lietti, L.; Cattaneo, E.; Galimberti, D.; Fenoglio, C.; Cortini, F.; Scarpini, E.; et al. Selective DNA Methylation of BDNF Promoter in Bipolar Disorder: Differences Among Patients with BDI and BDII. Neuropsychopharmacology 2012, 37, 1647-1655. [CrossRef] [PubMed] 
50. D'Addario, C.; Dell'Osso, B.; Galimberti, D.; Palazzo, M.C.; Benatti, B.; Di Francesco, A.; Scarpini, E.; Altamura, A.C.; Maccarrone, M. Epigenetic Modulation of BDNF Gene in Patients with Major Depressive Disorder. Biol. Psychiatry 2013, 73, e6-e7. [CrossRef] [PubMed]

51. Carlberg, L.; Scheibelreiter, J.; Hassler, M.R.; Schloegelhofer, M.; Schmoeger, M.; Ludwig, B.; Kasper, S.; Aschauer, H.; Egger, G.; Schosser, A. Brain-derived neurotrophic factor (BDNF)-Epigenetic regulation in unipolar and bipolar affective disorder. J. Affect. Disord. 2014, 168, 399-406. [CrossRef]

52. Wang, P.; Zhang, C.; Lv, Q.; Bao, C.; Sun, H.; Ma, G.; Fang, Y.; Yi, Z.; Cai, W. Association of DNA methylation in BDNF with escitalopram treatment response in depressed Chinese Han patients. Eur. J. Clin. Pharm. 2018, 74, 1011-1020. [CrossRef]

53. Januar, V.; Ancelin, M.L.; Ritchie, K.; Saffery, R.; Ryan, J. BDNF promoter methylation and genetic variation in late-life depression. Transl. Psychiatry 2015, 5, e619. [CrossRef]

54. Kang, H.J.; Kim, J.M.; Lee, J.Y.; Kim, S.Y.; Bae, K.Y.; Kim, S.W.; Shin, I.S.; Kim, H.R.; Shin, M.G.; Yoon, J.S. BDNF promoter methylation and suicidal behavior in depressive patients. J. Affect. Disord. 2013, 151, 679-685. [CrossRef]

55. Tadić, A.; Müller-Engling, L.; Schlicht, K.F.; Kotsiari, A.; Dreimüller, N.; Kleimann, A.; Bleich, S.; Lieb, K.; Frieling, H. Methylation of the promoter of brain-derived neurotrophic factor exon IV and antidepressant response in major depression. Mol. Psychiatry 2014, 19, 281-283. [CrossRef] [PubMed]

56. Dreimüller, N.; Schlicht, K.F.; Wagner, S.; Peetz, D.; Borysenko, L.; Hiemke, C.; Lieb, K.; Tadić, A. Early reactions of brain-derived neurotrophic factor in plasma ( $\mathrm{pBDNF}$ ) and outcome to acute antidepressant treatment in patients with Major Depression. Neuropharmacology 2012, 62, 264-269. [CrossRef] [PubMed]

57. Kim, J.M.; Stewart, R.; Kang, H.J.; Bae, K.Y.; Kim, S.W.; Shin, I.S.; Hong, Y.J.; Ahn, Y.; Jeong, M.H.; Yoon, J.S. $B D N F$ methylation and depressive disorder in acute coronary syndrome: The K-DEPACS and EsDEPACS studies. Psychoneuroendocrinology 2015, 62, 159-165. [CrossRef] [PubMed]

58. Chen, E.S.; Ernst, C.; Turecki, G. The epigenetic effects of antidepressant treatment on human prefrontal cortex BDNF expression. Int. J. Neuropsychopharmacol. 2011, 14, 427-429. [CrossRef]

59. Lopez, J.P.; Mamdani, F.; Beaulieu, M.M.; Yang, J.P.; Berlim, M.T.; Ernst, C.; Turecki, G. Epigenetic regulation of BDNF expression according to antidepressant response. Mol. Psychiatry 2013, 18, 398-399. [CrossRef]

60. Meyer, J.H.; Ginovart, N.; Boovariwala, A.; Sagrati, S.; Hussey, D.; Garcia, A.; Young, T.; Praschak-Rieder, N.; Wilson, A.A.; Houle, S. Elevated monoamine oxidase a levels in the brain: An explanation for the monoamine imbalance of major depression. Arch. Gen. Psychiatry 2006, 63, 1209-1216. [CrossRef]

61. McDermott, R.; Tingley, D.; Cowden, J.; Frazzetto, G.; Johnson, D.D.P. Monoamine oxidase A gene (MAOA) predicts behavioral aggression following provocation. Proc. Natl. Acad. Sci. USA 2009, 106, 2118-2123. [CrossRef]

62. Godar, S.C.; Bortolato, M.; Richards, S.E.; Li, F.G.; Chen, K.; Wellman, C.L.; Shih, J.C. Monoamine Oxidase A is Required for Rapid Dendritic Remodeling in Response to Stress. Int. J. Neuropsychopharmacol. 2015, 18. [CrossRef]

63. Wang, C.C.; Borchert, A.; Ugun-Klusek, A.; Tang, L.Y.; Lui, W.T.; Chu, C.Y.; Billett, E.; Kuhn, H.; Ufer, C. Monoamine Oxidase A Expression Is Vital For Embryonic Brain Development By Modulating Developmental Apoptosis. J. Biol. Chem. 2011, 286, 28322-28330. [CrossRef]

64. Checknita, D.; Ekström, T.J.; Comasco, E.; Nilsson, K.W.; Tiihonen, J.; Hodgins, S. Associations of monoamine oxidase A gene first exon methylation with sexual abuse and current depression in women. J. Neural. Transm. (Vienna) 2018, 125, 1053-1064. [CrossRef]

65. Domschke, K.; Tidow, N.; Schwarte, K.; Ziegler, C.; Lesch, K.P.; Deckert, J.; Arolt, V.; Zwanzger, P.; Baune, B.T. Pharmacoepigenetics of depression: No major influence of $M A O-A$ DNA methylation on treatment response. J. Neural. Transm. 2015, 122, 99-108. [CrossRef]

66. Luddington, N.S.; Mandadapu, A.; Husk, M.; El-Mallakh, R.S. Clinical Implications of Genetic Variation in the Serotonin Transporter Promoter Region: A Review. Prim. Care Companion J. Clin. Psychiatry 2009, 11, 93-102. [CrossRef] [PubMed]

67. Booij, L.; Szyf, M.; Carballedo, A.; Frey, E.-M.; Morris, D.; Dymov, S.; Vaisheva, F.; Ly, V.; Fahey, C.; Meaney, J.; et al. DNA Methylation of the Serotonin Transporter Gene in Peripheral Cells and Stress-Related Changes in Hippocampal Volume: A Study in Depressed Patients and Healthy Controls. PLoS ONE 2015, 10, e0119061. [CrossRef] [PubMed] 
68. Kang, H.J.; Kim, J.M.; Stewart, R.; Kim, S.Y.; Bae, K.Y.; Kim, S.W.; Shin, I.S.; Shin, M.G.; Yoon, J.S. Association of SLC6A4 methylation with early adversity, characteristics and outcomes in depression. Prog. Neuropsychopharmacol. Biol. Psychiatry 2013, 44, 23-28. [CrossRef] [PubMed]

69. Domschke, K.; Tidow, N.; Schwarte, K.; Deckert, J.; Lesch, K.P.; Arolt, V.; Zwanzger, P.; Baune, B.T. Serotonin transporter gene hypomethylation predicts impaired antidepressant treatment response. Int. J. Neuropsychopharmacol. 2014, 17, 1167-1176. [CrossRef]

70. Iga, J.; Watanabe, S.Y.; Numata, S.; Umehara, H.; Nishi, A.; Kinoshita, M.; Inoshita, M.; Shimodera, S.; Fujita, H.; Ohmori, T. Association study of polymorphism in the serotonin transporter gene promoter, methylation profiles, and expression in patients with major depressive disorder. Hum. Psychopharmacol. 2016, 31, 193-199. [CrossRef]

71. Okada, S.; Morinobu, S.; Fuchikami, M.; Segawa, M.; Yokomaku, K.; Kataoka, T.; Okamoto, Y.; Yamawaki, S.; Inoue, T.; Kusumi, I.; et al. The potential of SLC6A4 gene methylation analysis for the diagnosis and treatment of major depression. J. Psychiatr. Res. 2014, 53, 47-53. [CrossRef]

72. Bayles, R.; Baker, E.K.; Jowett, J.B.M.; Barton, D.; Esler, M.; El-Osta, A.; Lambert, G. Methylation of the SLC6a2 Gene Promoter in Major Depression and Panic Disorder. PLoS ONE 2013, 8, e83223. [CrossRef]

73. Kato, M.; Fukuda, T.; Wakeno, M.; Okugawa, G.; Takekita, Y.; Watanabe, S.; Yamashita, M.; Hosoi, Y.; Azuma, J.; Kinoshita, T.; et al. Effect of 5-HT1A Gene Polymorphisms on Antidepressant Response in Major Depressive Disorder. Am. J. Med. Genet. B Neuopsychiatr. Genet. 2009, 150B, 115-123. [CrossRef]

74. Yohn, C.N.; Gergues, M.M.; Samuels, B.A. The role of 5-HT receptors in depression. Mol. Brain 2017, 10, 28. [CrossRef]

75. Lerer, B.; Gelfin, Y.; Gorfine, M.; Allolio, B.; Lesch, K.P.; Newman, M.E. 5-HT1A Receptor Function in Normal Subjects on Clinical Doses of Fluoxetine: Blunted Temperature and Hormone Responses to Ipsapirone Challenge. Neuropsychopharmacology 1999, 20, 628-639. [CrossRef]

76. Lotrich, F.E.; Pollock, B.G. Candidate genes for antidepressant response to selective serotonin reuptake inhibitors. Neuropsychiatr. Dis. Treat. 2005, 1, 17-35. [CrossRef] [PubMed]

77. Wang, P.; Lv, Q.; Mao, Y.; Zhang, C.; Bao, C.; Sun, H.; Chen, H.; Yi, Z.; Cai, W.; Fang, Y. HTR1A/1B DNA methylation may predict escitalopram treatment response in depressed Chinese Han patients. J. Affect. Disord. 2018, 228, 222-228. [CrossRef] [PubMed]

78. Gassó, P.; Rodríguez, N.; Blázquez, A.; Monteagudo, A.; Boloc, D.; Plana, M.T.; Lafuente, A.; Lázaro, L.; Arnaiz, J.A.; Mas, S. Epigenetic and genetic variants in the HTR1B gene and clinical improvement in children and adolescents treated with fluoxetine. Prog. Neuropsychopharmacol. Biol. Psychiatry 2017, 75, 28-34. [CrossRef] [PubMed]

79. Strawbridge, R.; Arnone, D.; Danese, A.; Papadopoulos, A.; Herane Vives, A.; Cleare, A.J. Inflammation and clinical response to treatment in depression: A meta-analysis. Eur. Neuropsychopharmacol 2015, 25, 1532-1543. [CrossRef] [PubMed]

80. Barnes, J.; Mondelli, V.; Pariante, C.M. Genetic Contributions of Inflammation to Depression. Neuropsychopharmacology 2017, 42, 81-98. [CrossRef]

81. Zhang, C.; Wu, Z.; Zhao, G.; Wang, F.; Fang, Y. Identification of IL6 as a susceptibility gene for major depressive disorder. Sci. Rep. 2016, 6, 31264. [CrossRef]

82. Ryan, J.; Pilkington, L.; Neuhaus, K.; Ritchie, K.; Ancelin, M.L.; Saffery, R. Investigating the epigenetic profile of the inflammatory gene IL-6 in late-life depression. BMC Psychiatry 2017, 17, 354. [CrossRef]

83. Dahl, J.; Ormstad, H.; Aass, H.C.; Malt, U.F.; Bendz, L.T.; Sandvik, L.; Brundin, L.; Andreassen, O.A. The plasma levels of various cytokines are increased during ongoing depression and are reduced to normal levels after recovery. Psychoneuroendocrinology 2014, 45, 77-86. [CrossRef]

84. Uher, R.; Perroud, N.; Ng, M.Y.; Hauser, J.; Henigsberg, N.; Maier, W.; Mors, O.; Placentino, A.; Rietschel, M.; Souery, D.; et al. Genome-Wide Pharmacogenetics of Antidepressant Response in the GENDEP Project. Am. J. Psychiatry 2010, 167, 555-564. [CrossRef]

85. Powell, T.R.; Smith, R.G.; Hackinger, S.; Schalkwyk, L.C.; Uher, R.; McGuffin, P.; Mill, J.; Tansey, K.E. DNA methylation in interleukin-11 predicts clinical response to antidepressants in GENDEP. Transl. Psychiatry 2013, 3, e300. [CrossRef] [PubMed]

86. Takeuchi, N.; Nonen, S.; Kato, M.; Wakeno, M.; Takekita, Y.; Kinoshita, T.; Kugawa, F. Therapeutic Response to Paroxetine in Major Depressive Disorder Predicted by DNA Methylation. Neuropsychobiology 2017, 75, 81-88. [CrossRef] 
87. Bell, J.T.; Tsai, P.C.; Yang, T.P.; Pidsley, R.; Nisbet, J.; Glass, D.; Mangino, M.; Zhai, G.; Zhang, F.; Valdes, A.; et al. Epigenome-wide scans identify differentially methylated regions for age and age-related phenotypes in a healthy ageing population. PLoS Genet. 2012, 8, e1002629. [CrossRef] [PubMed]

88. Verhoeven, J.E.; Yang, R.; Wolkowitz, O.M.; Bersani, F.S.; Lindqvist, D.; Mellon, S.H.; Yehuda, R.; Flory, J.D.; Lin, J.; Abu-Amara, D.; et al. Epigenetic Age in Male Combat-Exposed War Veterans: Associations with Posttraumatic Stress Disorder Status. Mol. Neuropsychiatry 2018, 4, 90-99. [CrossRef] [PubMed]

89. Bus, B.A.A.; Molendijk, M.L. The neurotrophic hypothesis of depression. Tijdschr. Psychiatr. 2016, 58, $215-222$. [PubMed]

90. Tadić, A.; Wagner, S.; Schlicht, K.F.; Peetz, D.; Borysenko, L.; Dreimüller, N.; Hiemke, C.; Lieb, K. The early non-increase of serum BDNF predicts failure of antidepressant treatment in patients with major depression: A pilot study. Prog. Neuropsychopharmacol. Biol. Psychiatry 2011, 35, 415-420. [CrossRef] [PubMed]

91. Li, M.; D'Arcy, C.; Li, X.; Zhang, T.; Joober, R.; Meng, X. What do DNA methylation studies tell us about depression? A systematic review. Transl. Psychiatry 2019, 9, 68. [CrossRef]

92. Davies, M.N.; Volta, M.; Pidsley, R.; Lunnon, K.; Dixit, A.; Lovestone, S.; Coarfa, C.; Harris, R.A.; Milosavljevic, A.; Troakes, C.; et al. Functional annotation of the human brain methylome identifies tissue-specific epigenetic variation across brain and blood. Genome Biol. 2012, 13, R43. [CrossRef]

93. Braun, P.R.; Han, S.; Hing, B.; Nagahama, Y.; Gaul, L.N.; Heinzman, J.T.; Grossbach, A.J.; Close, L.; Dlouhy, B.J.; Howard, M.A.; et al. Genome-wide DNA methylation comparison between live human brain and peripheral tissues within individuals. Transl. Psychiat. 2019, 9. [CrossRef]

94. Rudge, J.S.; Eaton, M.J.; Mather, P.; Lindsay, R.M.; Whittemore, S.R. CNTF Induces Raphe Neuronal Precursors to Switch from a Serotonergic to a Cholinergic Phenotype in Vitro. Mol. Cell Neurosci. 1996, 7, $204-221$. [CrossRef]

95. Teschendorff, A.E.; West, J.; Beck, S. Age-associated epigenetic drift: Implications, and a case of epigenetic thrift? Hum. Mol. Genet. 2013, 22, R7-R15. [CrossRef] [PubMed]

96. Holliday, R.; Pugh, J.E. DNA modification mechanisms and gene activity during development. Science 1975, 187, 226-232. [CrossRef] [PubMed]

97. Gentile, S.; Fusco, M.L. Placental and fetal effects of antenatal exposure to antidepressants or untreated maternal depression. J. Matern. Fetal Neonatal. Med. 2017, 30, 1189-1199. [CrossRef] [PubMed]

98. Du Prel, J.B.; Röhrig, B.; Blettner, M. Critical Appraisal of Scientific Articles Part 1 of a Series on Evaluation of Scientific Publications. Dtsch. Arztebl. Int. 2009, 106, 100-105. [CrossRef] [PubMed]

99. Moher, D.; Liberati, A.; Tetzlaff, J.; Altman, D.G.; The, P.G. Preferred Reporting Items for Systematic Reviews and Meta-Analyses: The PRISMA Statement. PLoS Med. 2009, 6, e1000097. [CrossRef] 